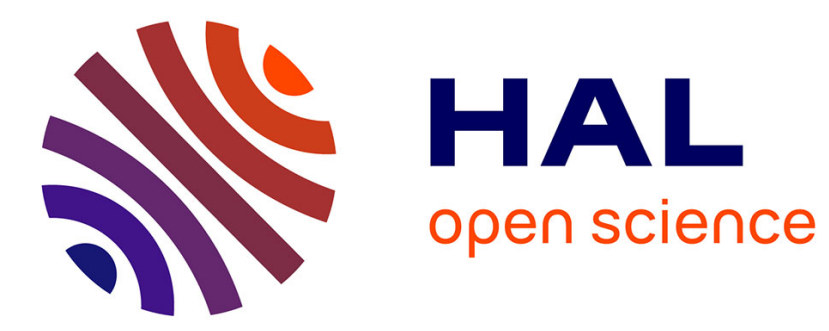

\title{
Pyk2 is essential for astrocytes mobility following brain lesion
}

\author{
Albert Giralt, Renata Coura, Jean-antoine Girault
}

\section{To cite this version:}

Albert Giralt, Renata Coura, Jean-antoine Girault. Pyk2 is essential for astrocytes mobility following brain lesion. Glia, 2016, 64 (4), pp.620-634. 10.1002/glia.22952 . hal-01286068

\section{HAL Id: hal-01286068 https://hal.sorbonne-universite.fr/hal-01286068}

Submitted on 10 Mar 2016

HAL is a multi-disciplinary open access archive for the deposit and dissemination of scientific research documents, whether they are published or not. The documents may come from teaching and research institutions in France or abroad, or from public or private research centers.
L'archive ouverte pluridisciplinaire $\mathbf{H A L}$, est destinée au dépôt et à la diffusion de documents scientifiques de niveau recherche, publiés ou non, émanant des établissements d'enseignement et de recherche français ou étrangers, des laboratoires publics ou privés. 


\title{
Pyk2 is essential for astrocytes mobility following brain lesion
}

\author{
Albert Giralt ${ }^{1,2,3}$, Renata Coura ${ }^{1,2,3}$, Jean-Antoine Girault ${ }^{1,2,3}$ \\ ${ }^{1}$ Inserm UMR-S839, 75005 Paris, France \\ ${ }^{2}$ Université Pierre et Marie Curie (UPMC, Paris 6), Sorbonne Universités, 75005 Paris, France \\ ${ }^{3}$ Institut du Fer à Moulin, 75005 Paris, France
}

Running title: Pyk2 in astrogliosis

Number of words: Total, 9373

Abstract: 245

Introduction: 539

Materials and methods: 1729

Results: 2184

Discussion: 896

Acknowledgements: 50

Bibliography: 2310

Figure legends: 1420

Figures: 7 ; no Table

Correspondence to: Jean-Antoine Girault

Inserm UMR-S839

Institut du Fer à Moulin

17 rue du Fer à Moulin

75005 Paris, France

+33145876152

jean-antoine.girault@inserm.fr

Main Points (TOCl submitted separately)

- $\mathrm{Pyk}^{-/}$astrocytes migration is slow after brain mechanical injury and in in vitro wound healing

- Without Pyk2 actin dynamics and turnover are altered

- $P y k 2$ is essential for gelsolin re-distribution at the leading edge of migrating astrocytes

Key words: Gelsolin, wound healing, actin polymerization, lamellipodia, filopodia 


\section{ABSTRACT}

Proline-rich tyrosine kinase 2 (Pyk2) is a calcium-dependent, non-receptor protein-tyrosine kinase of the focal adhesion kinase (FAK) family. Pyk2 is enriched in the brain, especially the forebrain. Pyk2 is highly expressed in neurons but is also present in astrocytes, where its role is not known. We used Pyk2 knockout mice $\left(\mathrm{Pyk}^{-/}\right)$developed in our laboratory to investigate the function of Pyk2 in astrocytes. Morphology and basic properties of astrocytes in vivo and in culture were not altered in the absence of Pyk2. However, following stab lesions in the motor cortex, astrocytes-mediated wound filling was slower in Pyk2 ${ }^{-/-}$than in wild type littermates. In an in vitro wound healing model, Pyk $2^{--}$astrocytes migrated slower than $\mathrm{Pyk}^{+/+}$astrocytes. The role of Pyk2 in actin dynamics was investigated by treating astrocytic cultures with the actin-depolymerizing drug latrunculin B. Actin filaments repolymerization after latrunculin B treatment was delayed in Pyk2 $\%$ astrocytes as compared to wild type astrocytes. We mimicked wound-induced activation by treating astrocytes in culture with tumor-necrosis factor alpha (TNF $\alpha)$, which increased Pyk2 phosphorylation at Tyr402. TNF $\alpha$ increased PKC activity, and Rac1 phosphorylation at Ser71 similarly in wild type and Pyk2-deficient astrocytes. Conversely, we found that gelsolin, an actin-capping protein known to interact with Pyk2 in other cell types, was less enriched at the leading edge of migrating Pyk2 ${ }^{--}$astrocytes, suggesting that its lack of recruitment mediated in part the effects of the mutation. This work shows the critical role of Pyk2 in astrocytes migration during wound healing. 


\section{INTRODUCTION}

The central nervous system (CNS) responds to trauma by producing a scar, which is primarily comprised of reactive astroglia (Pekny and Nilsson 2005). In mammals, the glial scar has beneficial as well as negative properties: it allows prompt repair of the blood-brain barrier, inhibits the entry of inflammatory cells into damaged brain, and limits neuronal death (Bush et al. 1999), but also impairs axonal regeneration (McGraw et al. 2001) and incorporation of neuronal grafts (Kinouchi et al. 2003). Following focal CNS injury, a subset of astrocytes or astroglial precursors throughout the brain undergo mitosis and morphological changes to yield reactive astroglia, which migrates towards the lesion and organizes into a densely packed glial scar (Hampton et al. 2004; Wang et al. 2004). This migration process is dependent on actin dynamics (Cowin 2005; Cowin et al. 2003) placing this cytoskeletal protein at a convergence point of many important intracellular pathways. However, although some mechanisms modulating this phenomenon have been described, the entire molecular framework is not fully understood.

Focal adhesion kinase (FAK) family proteins have been described to play a role in cell migration during different conditions and paradigms (Tomar and Schlaepfer 2009). Prolinerich tyrosine kinase 2 (Pyk2) is a non-receptor, calcium-dependent protein-tyrosine kinase that belongs to the FAK family (Lev et al. 1995; Sasaki et al. 1995). Whereas FAK is expressed in all tissues, Pyk2 is highly enriched in the brain, especially the forebrain where it is regulated by neuronal activity and may be involved in synaptic plasticity (Girault et al. 1999; Huang et al. 2001; Siciliano et al. 1996). However, although Pyk2 is highly expressed in neurons (Menegon et al. 1999) it is also present in astrocytes (Cazaubon et al. 1997). The role of Pyk2 in peripheral tissues has been previously investigated using knockout mice, implicating Pyk2 in macrophages morphology and migration (Okigaki et al. 2003), neutrophils degranulation (Kamen et al. 2011), bone formation and degradation (Buckbinder et al. 2007; Gil-Henn et al. 2007), protection against cardiac arrhythmia (Lang et al. 2011), and skin wound repair (Koppel et al. 2014). In contrast, the effects of this deletion on the nervous system has not been explored. Despite the fact that the role of Pyk2 in astrocytes is completely elusive, its involvement in several pathways capable to modulate actin dynamics in other cell types (Lim et al. 2008; Murasawa et al. 2000; Ying et al. 2009) led us to hypothesize that Pyk2 could regulate astrocytes migration targeted to form the glial scar after physical lesion. 
To address directly the function of Pyk2 in the brain we have generated Pyk2 knockout mice in our laboratory. Since we found that many aspects of astrocytes morphology and physiology were unaltered in $\mathrm{Pyk}^{-\%}$ mice, we focused on astrocytes reactivity and function after a physical lesion into the brain. We observed that astrocytes from Pyk2 $2^{-1-}$ mice displayed a slower wound covering as compared to wild type littermate mice after a mechanical stab lesion. We confirmed these data in purified astrocytes in vitro. We then observed that actin polymerization dynamics was altered in $\mathrm{Pyk} 2^{-/}$astrocytes. Gelsolin, an actin-capping protein able to interact with Pyk2, was mislocalized in Pyk2 ${ }^{-/}$ migrating astrocytes compared to $\mathrm{Pyk}^{+/+}$astrocytes, providing a possible link to the role of Pyk2 in cell migration.

\section{MATERIALS AND METHODS}

\section{Pyk2 mutant mice}

We have generated a new line of Pyk2 knock-out mice in collaboration with Gen-O-way (Lyon, France). The model was generated by homologous recombination in embryonic stem (ES) cells and the following strategy was used: a targeting vector containing regions homologous to the genomic Pyk2 sequences was constructed for deletion of the Pyk2 exons 15 to 18 (Fig. 1A), corresponding to the kinase domain. Splicing between exons 14 and 19 is out of frame, resulting in a premature STOP codon in exon 19. Mice were genotyped from tail biopsy by Charles River (Erkrath, Germany). The primers used for DNA amplification were: Pyk2 forward: 5'-TGTGCTCAGAGAAAAACGGAGGAACCCT-3', Pyk2 reverse 1: 5'CATTGATTCCTGCTTCAGCCCTGGTCTAA-3' and Pyk2 reverse 2: 5'GCCCATCGGGGCGATTTAAATATAATTCG-3'. Breeding strategy generated Pyk2 ${ }^{+/+}$, Pyk2 ${ }^{+/-}$and $\mathrm{Pyk}^{-/-}$mice at the expected Mendelian ratios. The animals were housed with access to food and water ad libitum in a colony room kept at $19-22^{\circ} \mathrm{C}$ and $40-60 \%$ humidity, under a $12: 12$ $\mathrm{h}$ light/dark cycle. Animals were used in accordance with the ethical guidelines (Declaration of Helsinki and NIH, publication no. 85-23, revised 1985, European Community Guidelines, and French Agriculture and Forestry Ministry guidelines for handling animals, decree 87849, license A 75-05-22) and approved by the local ethical committees. 


\section{Stab lesions}

We performed stab lesions in adult $\mathrm{Pyk2}^{+/+}, \mathrm{Pyk}^{+/-}$and $\mathrm{Pyk} 2^{-{ }^{-}}$mice as previously described (Saadoun et al. 2005). Briefly, mice were anesthetized with a mixture of xylazine $(10 \mathrm{mg} / \mathrm{ml})$ and ketamine $(25 \mathrm{mg} / \mathrm{ml}$ ) (Centravet) and mounted in a digitalized stereotactic frame (Stoelting Europe) equipped with a mouse adaptor. After incising the skin, a 27G X 3/4" $0.4 \times 20 \mathrm{~mm}$ needle was directly introduced through the skull at the following coordinates (in millimeters): $A P,+0.6, L,+2.0$ from bregma and $D V,-2.7$ from skull. After $1 \mathrm{~min}$, the needle was removed and the skin was sutured. Mice were maintained in animal house conditions during $72 \mathrm{~h}$ and then sacrificed.

\section{Stab lesion characterization}

The volume of the stab lesion and the region with reactive astrogliosis was measured using the Cavalieri's method, as previously described (Giralt et al. 2010), by evaluating coronal sections spaced $80 \mu \mathrm{m}$ apart. We also calculated the $\%$ of orientated cells/field in these coronal sections as described (Nagaoka et al. 2012). Briefly, we considered an astrocyte to be orientated when it projected the majority of processes to the wound direction (perpendicular to the wound). Only astrocytes within a $90 \mu \mathrm{m}$ field surrounding the wound were considered.

\section{Tissue fixation and immunofluorescence}

Animals were deeply anesthetized with pentobarbital $(60 \mathrm{mg} / \mathrm{kg})$ and intracardially perfused with a $4 \%$ (weight/vol) paraformaldehyde solution in $0.12 \mathrm{M}$ sodium phosphate, $\mathrm{pH} 7.2$. Brains were removed and post-fixed overnight in the same solution, cryoprotected with 300 $\mathrm{g} / \mathrm{l}$ sucrose in $20 \mathrm{mM}$ sodium phosphate, $\mathrm{pH} 7.5,150 \mathrm{mM} \mathrm{NaCl}$ (PBS) with $0.2 \mathrm{~g} / \mathrm{l}$ sodium azide and frozen in dry ice-cooled isopentane. Serial coronal sections ( $30 \mu \mathrm{m})$ obtained with a cryostat were processed for immunohistochemistry as free floating sections. They were washed three times in PBS, permeabilized 15 min by shaking at room temperature with PBS containing ( $\mathrm{vol} / \mathrm{vol}$ ) 0.3\% Triton X-100 and 3\% normal goat serum (Pierce Biotechnology, Rockford, IL, USA). After three washes, brain sections were incubated overnight (o.n.) by shaking at $4^{\circ} \mathrm{C}$ with antibodies for glial fibrillary acidic protein (GFAP, 1:200, rabbit polyclonal Z033429, DAKO A/S, Glostrup, Germany) or Pyk2 (1:400, mouse monoclonal 610549, BD 
Transduction Laboratories, San Diego CA, USA) in PBS with $0.2 \mathrm{~g} / \mathrm{l}$ sodium azide. After incubation with primary antibody, sections were washed three times and then placed $2 \mathrm{~h}$ on a shaking incubator at room temperature with the subtype-specific fluorescent secondary 488 anti-rabbit (1:250, Molecular Probes, Sunnyvale, CA). No signal was detected in control sections incubated in the absence of the primary antibody. Nissl staining was performed as described elsewhere (Giralt et al. 2010).

\section{Astrocytes cultures}

Primary cortical astrocyte cultures were obtained from P1 to P3 Pyk2 ${ }^{+/+}, \mathrm{Pyk} 2^{+/-}$, and Pyk2 ${ }^{-/-}$ mouse pups by cortical dissection and removal of the meninges. Extracted tissue was dissociated and placed in $25 \mathrm{~cm}^{2}$ flasks in a modified minimum Eagle's medium called NM-15 (200 g/l fetal bovine serum; Gibco-BRL, Renfrewshire, Scotland, UK; D-Glucose 90 mM; Buchs, Switzerland) with L-glutamine (2 mM) and Earle's salts (Gibco-BRL) and placed in an incubator at $37^{\circ} \mathrm{C}$ with $5 \% \mathrm{CO}_{2}$. Medium was changed every 3 days. Cells were cultured separately for each pup and a tail biopsy was obtained for genotyping. After two passages, the cultures were purified by agitating in a shaker $16-18 \mathrm{~h}$ at 250 r.p.m. Finally, medium with floating cells was replaced with new medium. This protocol provides cultures with a $\sim 95 \%$ of astrocytes purity (Giralt et al. 2010).

\section{Adhesion and proliferation assays}

We performed adhesion and proliferation assays as previously described (Saadoun et al. 2005). Confluent cultured astroglia were trypsinized and suspended in NM-15. After measurement of cell density using a hemocytometer, $2.8 \times 10^{4}$ cells per $\mathrm{cm}^{2}$ were plated in 24-well plates coated with poly-D-lysine (Sigma). The medium was exchanged 4 hours after plating. Adhesion was defined as the percentage of plated cells remaining immediately after medium exchange. To assess proliferation, the number of cells per well was determined every 2 days by trypsinization and cell counting.

\section{Immunocytochemistry}

Cells were fixed $10 \mathrm{~min}$ in a $40 \mathrm{~g} / \mathrm{l}$ paraformaldehyde solution and, after 3 washes with PBS, cells were permeabilized $10 \mathrm{~min}$ with triton X-100 in PBS (0.1\% vol/vol). Unspecific binding was blocked $30 \mathrm{~min}$ in $2 \%$ (vol/vol) normal goat serum and $30 \mathrm{~g} / \mathrm{l} \mathrm{BSA}$ in PBS. Then, cells 
were incubated with rabbit polyclonal antibodies for gelsolin (1:300, ab113229, Abcam Cambridge, UK), GFAP (1:500, Z033429, DAKO A/S, Glostrup, Germany) or Pyk2 (1:400, p3902, Sigma) overnight in a shaker at $4^{\circ} \mathrm{C}$. After washes, cells were incubated $2 \mathrm{~h}$ with Alexa-488- or 555-coupled secondary antibodies (1:300, Sunnyvale), washed, labeled with rhodamine-phalloidin (1:1000, Sigma) during $40 \mathrm{~min}$, washed again, labeled with 40,60diamidino-2-phenylindole (DAPI), and mounted in Vectashield medium. Imaging of the immunostaining was carried out with a DM6000-2 microscope (Leica) and analyzed with the ImageJ software.

\section{Wound healing}

As previously described (Holtje et al. 2005), confluent astrocytes monolayers growing on glass coverslips were used for scratch assays. Two perpendicular wounds of $\sim 225 \mu \mathrm{m}$ in width were scratched with sterile P100 tips. Cells were fixed 0, 24 or $48 \mathrm{~h}$ after wounding, stained with rhodamine-phalloidin (Sigma) and DAPI (see above), and photomicrographs were taken. Individual images (4 per scratch wound) taken with the $10 \times$ magnification sections were obtained on a DM6000-2 microscope (Leica). The re-population of the lesion site over the whole wound was analyzed by measuring the cell-free area (in $\mu \mathrm{m}^{2}$ ) using the ImageJ software.

\section{In vitro actin repolymerization assay}

Astrocytes (50-60\% confluence) were treated with $1 \mu \mathrm{M}$ latrunculin B (Calbiochem, San Diego, CA, USA) during 45 min with NM-15 without serum and then medium was removed and substituted by a normal NM-15. Cells were fixed at 0,15 or $60 \mathrm{~min}$ after latrunculin B treatment. Control cells with no treatment were also fixed as control/baseline. Cells were stained for rhodamine-phalloidin (Sigma) and DAPI (see above). Total cellular area was analyzed using the ImageJ software.

\section{Confocal imaging}

Fluorescently stained coronal sections (cerebral cortex M1 region) or fixed astrocytes cultures were examined by confocal microscopy, using a Leica SP5 laser scanning confocal spectral microscope with argon and helium-neon lasers. Images were taken from mouse tissue or fixed cells with a $63 \times$ numerical aperture lens with $4 \times$ digital zoom respectively and 
standard (one Airy disc) pinhole. For each image obtained in tissue, the entire threedimensional stack of images was obtained by the use of the $Z$ drive present in the Leica SP5 microscope with a separation of $2 \mu \mathrm{m}$ between each one. For each image obtained in fixed cells, we focused on leading edges of migrating astrocytes, acquiring $0.5-\mu m$ separated stacks, which were used for analysis of the gelsolin positive area and mean intensity. Images were analyzed by the freeware NIH ImageJ version 1.33 by Wayne Rasband (National Institutes of Health, Bethesda, MD). The morphological analysis of labeled GFAP-positive astrocytes was performed by using the Sholl approach in the same software.

\section{Immunoblot analysis}

Mice were deeply anesthetized in a $\mathrm{CO}_{2}$ chamber, the brains quickly removed, cortex dissected out, frozen in dry ice and stored at $-80^{\circ} \mathrm{C}$ until use. Briefly, tissue was sonicated in $250 \mathrm{ml}$ of lysis buffer (PBS, 1\% Nonidet P40 [vol/vol], $1 \mathrm{~g} / \mathrm{l} \mathrm{SDS}, 5 \mathrm{~g} / \mathrm{l}$ sodium deoxycholate, protease inhibitors cocktail 1:1000 (Sigma), and $2 \mathrm{~g} / \mathrm{l}$ sodium orthovanadate) and centrifuged at 12000 r.p.m. for $20 \mathrm{~min}$ and the pellet was discarded. For in vitro studies, confluent astrocytes were stimulated during $15 \mathrm{~min}$ in serum-free medium containing 10 $\mathrm{ng} / \mathrm{ml}$ of TNF $\alpha$ (Sigma) or only vehicle and cell homogenates were obtained at 15 or $60 \mathrm{~min}$ after TNF $\alpha$ treatment. Cells were lysed in lysis buffer (as above). Proteins (15 mg) from cortex tissue or from astroglial cultures were analyzed by SDS-polyacrylamide gel electrophoresis $(7.5 \%$ acrylamide, weight/vol) and transferred to nitrocellulose membranes (Millipore, Bedford, MA, USA). Membranes were blocked in TBS-T (150 mM NaCl, $20 \mathrm{mM}$ Tris- $\mathrm{HCl}, \mathrm{pH} 7.5,0.05 \%$ [vol/vol] Tween 20) with $50 \mathrm{~g} / \mathrm{l}$ non-fat dry milk and $50 \mathrm{~g} / \mathrm{l} \mathrm{BSA}$. Immunoblots were probed with rabbit polyclonal antibodies for Cdc42 (1:1000, ab14241, Abcam, Cambridge, UK), gelsolin (1:1000, ab113229, Abcam), GFAP (1:1000, Z033429, DAKO A/S, Glostrup, Germany), PKC $\zeta$ (1:1000, 07-264 Merck-Millipore, Darmstadt, Germany), phospho-Ser PKC substrates (1:1000, 2261, Cell Signaling Technology, Beverly MA, USA), Pyk2 (1:1000, P3902, Sigma, Saint Louis MI, USA), phospho-Tyr402-Pyk2 (1:1000, 44618G, Invitrogen, Carlsbad, CA, USA), phospho-Ser71-Rac1/Cdc42 (1:1000, ab5482, Abcam), phospho-Ser188-RhoA (1:1000, RP1361, ECM Biosciences, Versailles KY, USA), S100B (1:1000, ab868, Abcam); or goat polyclonal antibodies for TrkB (1:1000, GT15080, Neuromics, Edina MN, USA); or mouse monoclonal antibodies for Rac1 (1:1000, 240106, Cell Biolabs), RhoA (1:1000, 240302, Cell Biolabs, San Diego CA, USA), Pyk2 (1:1000, 610549, BD 
Biosciences), or alpha-Tubulin (1:1000, T9026, Sigma). All blots were incubated overnight at $4^{\circ} \mathrm{C}$ with shaking, in the presence of the primary antibody in PBS with $0.2 \mathrm{~g} / \mathrm{l}$ sodium azide. After several washes in TBS-T, blots were incubated with anti-rabbit IgG IRdye800CWcoupled or anti-mouse IgG IRdye700DXcoupled antibodies (1/2000, Rockland Immunochemicals, USA) and signal detected by the Odyssey system (Li-Cor) and analyzed using ImageJ. A monoclonal $\alpha$-tubulin antibody (Sigma) was used as a loading control.

\section{Statistical analysis}

All results were expressed as the mean \pm s.e.m. for each genotype or group. For the statistical analysis of in vivo and in vitro experiments, unpaired Student's t-test, one-way ANOVA or two-way ANOVA were used as specified in the figure legends. $\mathrm{P}<0.05$ was considered significant.

\section{RESULTS}

\section{Brain gross anatomy and astrocytes in Pyk2 knockout mice}

We designed and generated a novel line of Pyk2 mutant mice in collaboration with Gen-oway (France). The strategy is summarized in Fig. 1A and detailed under Materials and Methods. Pyk2 ${ }^{+/+}, \mathrm{Pyk2}^{+/-}$and Pyk2 ${ }^{-/-}$mice were born at Mendelian frequencies $\left(\mathrm{Pyk2}^{+/+}, 24 \%\right.$, $\mathrm{Pyk}^{+/-}, 54 \%$, and $\mathrm{Pyk2}^{+/}, 22 \%$, from 115 genotyped mice at 4-6 weeks of age) and supervision of their home cages indicated that the gross behavior, general health, body weight (in grams at 12 weeks of age, Pyk2 ${ }^{+/+}, 30.80 \pm 1.05, \mathrm{Pyk}^{+/-}, 30.47 \pm 0.84$, and Pyk2 $2^{-/}$, $\left.30.16 \pm 1.02 ; F_{(2,25)}=0.09, p=0.9\right)$ and appearance of mice of the three genotypes were normal (Fig. 1B). Immunoblot analysis of hippocampal tissue, the brain region with the highest Pyk2 levels (Menegon et al. 1999), showed that total protein levels of Pyk2 were reduced around $50 \%$ in $\mathrm{Pyk} 2^{+/-}$mice compared to $\mathrm{Pyk} 2^{+/+}$mice and undetectable in $\mathrm{Pyk} 2^{-/-}$ mice (Fig. 1C and D). Accordingly, phosphorylation levels of Pyk2 Tyr402, its autophosphorylation site leading to its activation (Avraham et al. 2000), were reduced around $50 \%$ of wild type in $\mathrm{Pyk}^{+/-}$mice and undetectable in Pyk2 ${ }^{-/-}$mice (Fig. 1C and E). In wild type mice Pyk2 immunofluorescence was detected in most forebrain regions, especially in the hippocampus and also the cortex, striatum and amygdala (Fig. 1F). The immunofluorescence was reduced in heterozygous and undetectable in homozygous mutant mice (Fig. 1F). Importantly, the brain gross anatomy of $\mathrm{Pyk}^{+/-}$and $\mathrm{Pyk}^{-/-}$mice appeared 
normal (Fig. 1G) indicating that Pyk2 is not essential for the development of the central nervous system.

To assess the shape of astrocytes in Pyk2 knockout mice, we immunostained brain sections for GFAP and compared the appearance of astrocytes in wild type and mutant mice (Fig. 1H). The size and morphology of astrocytes were similar in the two genotypes. To assess more precisely the shape and branching of astrocytes we carried out a Sholl analysis (Fig. 1I), similar to what is usually done to evaluate the dendritic tree of neurons (Sholl 1953), but can also be applied to evaluate astrocytes complexity (Sullivan et al. 2010). There was no difference between wild type and Pyk2 lacking mice. These results showed the lack of gross brain defect in Pyk2 knockout mice as well as the absence of major astrocytic alteration.

\section{Astrocyte migration after cortical stab lesion is slowed in Pyk2 knockout mice}

To determine the role of Pyk2 in astroglial activation and cell migration in vivo, we studied reactive gliosis and glial scar formation using a well-established cortical-stab-injury model (Hampton et al. 2004; Wang et al. 2004). The stab-injury mouse model, unlike other brain injury models (tumor, infection, trauma), is not associated with significant brain swelling, which could confound interpretation of results (Saadoun et al. 2005). Three days after stab lesion, reactive astrocytes were identified by their multiple processes and strong glial fibrillary acidic protein (GFAP) immunoreactivity in the cortical M1 area in all genotypes (Fig. 2). In wild type mice, although Pyk2 immunoreactivity was much stronger in neurons than in astrocytes, double staining with GFAP revealed that Pyk2 was expressed in astrocytes migrating towards the stab lesion (Fig. 2A). We compared the speed of migration of reactive astroglia in $\mathrm{Pyk}^{+/+}, \mathrm{Pyk}^{+/-}$, and $\mathrm{Pyk}^{-/-}$mice by measuring the volume of the wound, determined by the absence of GFAP labeling, $72 \mathrm{~h}$ after stab lesion. Representative GFAPimmunolabeled brain sections and the quantified data (Fig. 2B, C) show that at $72 \mathrm{~h}$ the stab lesion area was almost covered by $\mathrm{Pyk2}^{+/+}$and Pyk2 $2^{+/-}$astrocytes. In contrast, the stab lesion area was significantly larger in $\mathrm{Pyk}^{-/-}$mice as compared to $\mathrm{Pyk} 2^{+/+}$mice (Fig. 2B, C) indicating a slower migration rate of $\mathrm{Pyk}^{-/-}$astrocytes. To rule out the possibility of defects in astrocytes orientation mechanisms or of decreased astroglial reactivity, we analyzed the orientation of astrocytes towards the wound and the area of the astrogliosis in $\mathrm{Pyk} 2^{+/+}$, $\mathrm{Pyk}^{+/-}$and $\mathrm{Pyk}^{-/-}$sections (Fig. 2D). We did not detect any significant differences between 
genotypes in the percentage of astroglial cells orientated towards the wound (Fig. 2E) or in the astrogliosis area (Fig. 2F). These results indicated that the activation of astrocytes was not modified in the absence of Pyk2, but that their migration was decreased.

\section{Pyk2 knockout does not alter basic properties of astrocytes in culture}

To better characterize the function of Pyk2 in astrocytes, we prepared primary cultures of astrocytes. We found that confluent astroglial cells cultured from $\mathrm{Pyk} 2^{+/+}$and $\mathrm{Pyk} 2^{-/-}$mice had similar appearance by phase-contrast microscopy (Fig. 3A) and similar GFAP expression and immunostaining (Fig. 3B). About 95\% of cells were stained for GFAP in wild type cultures, as described elsewhere (Giralt et al. 2010), as well as in Pyk2 ${ }^{-1-}$ cultures. We then labeled astrocytes for Pyk2 and F-actin. In wild type astrocytes, Pyk2 immunoreactivity had a punctate and diffused appearance throughout the cell body with no specific subcellular enrichment, except for a higher density in the perinuclear region (Fig. 3C). This distribution was similar to that reported in fibroblasts (Aoto et al. 2002; Sieg et al. 1998). In Pyk2/astrocytes, no Pyk2 immunoreactivity was observed, as expected, and the actin filaments looked comparable to those in Pyk2 ${ }^{+/+}$astrocytes (Fig. 3C).

To determine whether the absence of Pyk2 altered the basic properties of astrocytes in culture, we measured by immunoblotting the levels of GFAP and S100B, two proteins that are specifically enriched in astrocytes (Raponi et al. 2007), and found no significant change in Pyk2 knockout mice (Fig. 3D, E). Similarly TrkB an important receptor in astrocytes, which express both its full length and truncated form (T1) (Aroeira et al. 2015; Climent et al. 2000; Rose et al. 2003), was unchanged (Fig. 3D, E). We also examined whether cell growth was altered in Pyk2-deficient astrocytes. The cultured $\mathrm{Pyk}^{+/+}$and $\mathrm{Pyk}^{-/}$astroglia had comparable proliferation rates, as assessed by serial cell counting (Fig. 3F). Finally, we examined the adhesion properties of Pyk2-/- astrocytes and found they displayed a similar adhesion to poly-D-lysine substrate (Fig. 3G). Altogether these results indicate that the basic properties of astrocytes in culture are not altered in the absence of Pyk2.

\section{Wound healing migration deficits in Pyk2 ${ }^{-/-}$astrocytes are cell-autonomous}


To better characterize the astrocytes deficit in wound healing in vivo, we investigated whether Pyk2 was also necessary for astrocytes migration in vitro and whether the deficit was a cell-autonomous phenomenon. We studied reactive gliosis and wound repair using in purified astrocytes cultures a well-established in vitro wound healing model (Desai et al. 2004; Holtje et al. 2005; Liang et al. 2007). Since there was no phenotype in $\mathrm{Pyk}^{+/-}$mice in the stab lesion paradigm in vivo, we focused on the comparison between homozygous mutant and wild type astrocytes in culture. Primary astrocytes from newborn $\mathrm{Pyk}^{+/+}$and $\mathrm{Pyk}^{-/-}$littermate mice were then cultured to confluence (Fig. 4). The monolayers were scratch-wounded and the abilities of $\mathrm{Pyk}^{+/+}$and $\mathrm{Pyk} 2^{-/-}$astrocytes to heal the wound were compared. As shown in Fig. 4A, at 24 and $48 \mathrm{~h}$ post-wounding, $\mathrm{Pyk} 2^{-/-}$astrocytes exhibited a lower capability to fill and close the wound as compared to wild type cells. This was confirmed by the quantification of the wound area (cell-free area) in $\mathrm{Pyk}^{-/-}$astrocytes (Fig. 4B). Thus, the ability of $\mathrm{Pyk} 2^{-/-}$astrocytes to heal scratch wound in vitro was severely compromised, indicating that Pyk2 function and/or signaling in astrocytes is essential for scratch wound repair in this setting.

\section{Actin polymerization dynamics are altered in Pyk $2^{-/-}$astrocytes}

Pyk2 has been reported to be involved in cell migration in macrophages and K562 cell lines (Ovcharenko et al. 2013) and regulates actin organization in oocytes (Meng et al. 2006). Since wound healing-induced migration is dependent on actin dynamics (Cowin 2005), we examined whether this dynamics was impaired in astrocytes in the absence of Pyk2. Wild type or Pyk2-deficient primary mouse astrocytes were cultured to 50-60\% confluence and then treated with latrunculin B (Fig. 5A), a drug which sequesters G-actin and prevents Factin assembly, and previously used to study dynamics in astrocytes in vitro (Mitsushima et al. 2006; Tomas et al. 2003). We found that $15 \mathrm{~min}$ and $60 \mathrm{~min}$ after latrunculin $B$ treatment both $\mathrm{Pyk}^{+/+}$and $\mathrm{Pyk}^{-/-}$astrocytes were able to significantly re-polymerize G-actin to F-actin (Fig. 5A). To quantify the speed of repolymerization, we measured the total phalloidinpositive area per cell in the cultures at several time points after latrunculin B treatment. In $\mathrm{Pyk}^{-/-}$astrocytes repolymerization was significantly slower than in wild type astrocytes (Fig. 5B). These results suggested that actin dynamics are compromised in $\mathrm{Pyk} 2^{-/}$astrocytes, potentially accounting for their slower migration than wild type cells in the wound healing paradigm. 


\section{Regulation of Pyk2, PKC, and Rac1 by TNF $\alpha$ in astrocytes}

TNF $\alpha$ is produced by physical lesions in the brain (Tchelingerian et al. 1996) and attracts various cell types to the scar (Su et al. 2009). TNF $\alpha$ can be produced by astrocytes (Lieberman et al. 1989) and is active on these cells (Benveniste et al. 1989). Interestingly, Pyk2 was reported to be activated in response to TNF $\alpha$ treatment in cultured H9c2 cells (Yang et al. 2013). To mimic the molecular changes during wound healing and gliosis we therefore treated astrocytes in culture with TNF $\alpha(10 \mathrm{ng} / \mathrm{ml})$ or vehicle and measured phosphorylation of Pyk2 at tyrosine 402 (pY402-Pyk2, Fig. 6A). In Pyk2 ${ }^{+/+}$astrocytes pY402Pyk2 was significantly increased 15 min but not 60 min after TNF $\alpha$ treatment (Fig. 6A, B). As expected, no Pyk2 or pTyr402-Pyk2 signal was detected in Pyk2 ${ }^{-/-}$astrocytes samples (Fig. 6A). PKC is one of the signaling pathways downstream from TNF $\alpha$ in astrocytes (Norris et al. 1994) and PKC can activate Pyk2 (Lev et al. 1995). We first measured the level of PKC $\zeta$, an isoform prominently expressed in astrocytes (Gott et al. 1994) and reported to be activated

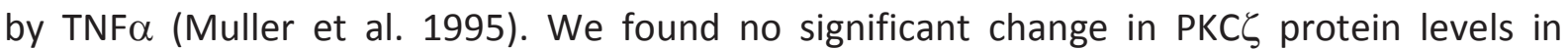
astrocytes between genotypes (Fig. 6C, Pyk2 ${ }^{+/+}: 100 \pm 12$, Pyk2 ${ }^{-/-}: 87 \pm 24$; arbitrary units; Student's t-test, $p=0.37)$. We then evaluated PKC activation using an antibody that detects phosphorylated serine/threonine in consensus region for PKC phosphorylation (Fig. 6C). PKCmediated phosphorylation was activated 15 min but not 60 min after TNF $\alpha$ treatment in both Pyk2 ${ }^{+/+}$and Pyk2 ${ }^{-/}$astrocytes (Fig. 6C, D). Since PKC can activate Pyk2 (Lev et al. 1995), this result was compatible with a role of PKC upstream but not downstream from Pyk2 activation in astrocytes in response to TNF $\alpha$.

Since actin dynamics during cell migration is dependent on small $\mathrm{G}$ proteins including Rac1 and RhoA (Ridley et al. 2003) we examined whether these proteins were altered in Pyk2-deficient astrocytes. Total protein levels of Rac $\left(\operatorname{Pyk}^{+/+}: 100 \pm 13, \operatorname{Pyk}^{-/-}: 113 \pm 21\right.$; Student's t-test, $p=0.35)$ and RhoA $\left(\mathrm{Pyk}^{+/+}: 100 \pm 29\right.$, Pyk2 $2^{-/-}: 104 \pm 15$; Student's t-test, $\mathrm{p}=$ 0.83 ) were not altered in Pyk2 ${ }^{-/}$as compared to Pyk $2^{+/+}$astrocytes. Then, since Akt, a kinase that can phosphorylate Cdc42/Rac1 at Ser71, can be activated by TNFa (Chung et al. 2015), we examined the phosphorylation of this residue in astrocytes. PhosphoSer71 was increased at both 15 and 60 min after TNF $\alpha$ treatment, in Pyk2 ${ }^{+/+}$as well as in Pyk2 ${ }^{-/-}$astrocytes, suggesting that the activation of this pathway was not altered by the mutation (Fig. 6E, F). Our results show that Pyk2 is activated in astrocytes in response to TNF $\alpha$, one of the factors 
involved in astrocytes recruitment by a brain injury, but that PKC activation and RhoA and Rac expression are unaltered in Pyk2 knockout cells.

\section{Gelsolin distribution is altered in migrating Pyk $2^{-/-}$astrocytes}

We next focused on a Pyk2 target that could be involved in the actin polymerization defects. Pyk2 has been shown to interact with gelsolin and to be involved in actin rings formation in osteoclasts during bones remodeling (Wang et al. 2003). Gelsolin is necessary for general motility of neutrophils, fibroblasts, and macrophages in culture (Goncalves et al. 2010; Witke et al. 1995). Gelsolin is also enriched in the filopodia of hippocampal neurons growth cone (Lu et al. 1997) and modulates stereocilia length via actin remodeling in cochlea (Mburu et al. 2010). We therefore tested gelsolin localization in migrating astrocytes and whether it could be involved in the impairments we observed in Pyk $2^{-/-}$astrocytes in the wound healing paradigm. Although the distribution of Pyk2 punctate immunofluorescence was widespread in migrating astrocytes, it was slightly enriched at the leading edge (Fig. 7A). As expected, 24 $\mathrm{h}$ after scratching astrocytes monolayer, gelsolin was specifically localized at the leading edge of migrating wild type astrocytes (Fig. 7B, upper panel). This enrichment appeared less pronounced in $\mathrm{Pyk}^{-/-}$astrocytes (Fig. 7B, lower panel). We therefore quantified gelsolin accumulation at the leading edge of $\mathrm{Pyk}^{+/+}$and $\mathrm{Pyk}^{-/-}$migrating astrocytes and we found a significantly smaller area (Fig. 7C) and reduced mean labeling intensity (Fig. 7D) in Pyk2 ${ }^{-/}$ migrating astrocytes as compared to wild type astrocytes. We then evaluated by immunoblot the total protein levels of gelsolin in both $\mathrm{Pyk} 2^{+/+}$and Pyk2 ${ }^{-/-}$astrocytes (Fig. 7E, F) and found no significant difference between genotypes. These results indicated that in the absence of Pyk2, gelsolin levels do not change whereas its distribution is impaired during the wound healing-induced migration.

\section{DISCUSSION}

Migration of reactive astroglia is an important component of glial scar formation around damaged brain tissue. Our in vitro data and in vivo experiments provide evidence for a specific role of Pyk2 in the migration of reactive astroglia towards the site of injury. In contrast, Pyk2 deletion did not affect other astroglial functions, such as astrogliosis, astrocytes orientation, adhesion, or proliferation. Moreover, our results indicate that actin 
dynamics are severely compromised in astrocytes lacking Pyk2. We found an altered gelsolin distribution during cell migration towards the site of injury. Thus, our data show that Pyk2 is specifically involved in astrocytes migration towards the site of injury during a physical lesion and that this process involves the recruitment of gelsolin to the cells leading edge.

Pyk2 in astrocytes received little attention so far. An early study showed Pyk2 activation during the formation of stress fibers in response to endothelin-1 (Cazaubon et al. 1997). In this study, Pyk2 activation was associated with ERK activation, but was independent of FAK, Rho, and Src kinases. In a recent study, a broad-spectrum tyrosine kinase inhibitor, quercetin, prevented astrogliosis and astrocyte migration, although the authors did not study Pyk2 (Yuan et al. 2015).

Actin rearrangement is crucial for cell motility and decreased actin turnover could severely affect cell migration during wound repair (Goicoechea et al. 2008; Ridley et al. 2003). In Pyk2-deficient astrocytes, we observed that actin dynamics were compromised, in agreement with the reported role of Pyk2 in actin rearrangement in 3T3-swiss cells (Du et al. 2001). Pyk2 could potentially modulate actin dynamics through various mechanisms including regulation of Rac1/RhoA/Cdc42 signaling (reviews in Ben-Ze'ev 1997; Kaibuchi et al. 1999; Ridley et al. 2003). Rac1 and Cdc42 are active and concentrated at the front edge of cells during migration in conditions such as in a wound repair (Ridley et al. 2003). As previously demonstrated, these pathways are directly or indirectly regulated by Pyk2. Pyk2 can activate Rac1 (Murasawa et al. 2000; Paulino et al. 2010) and Rac1-deficient mice suffer from deficient wound healing (Castilho et al. 2010). Pyk2 also activates Cdc42 (Ren et al. 2001) and RhoA (Lim et al. 2008). It is possible that a deficient activation of RhoA contributes to the deficient migration of Pyk2-/- astrocytes as suggested in the case of macrophages (Okigaki et al. 2003).

We examined signaling response in astrocytes treated with TNF $\alpha$, a factor released and increased after physical brain injury (Tchelingerian et al. 1996). TNFa is known to regulate actin (Deli et al. 1995) and calcium mobilization in astrocytes (Santello et al. 2011), as well as astrocytes migration to lesion sites (Su et al. 2009). Furthermore, TNF $\alpha$ can

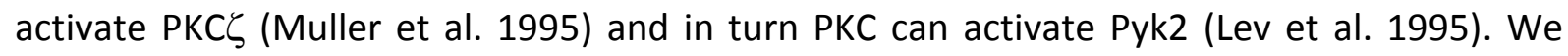
found evidence for activation of PKC signaling after TNF $\alpha$ treatment. TNF $\alpha$ also increased Pyk2 in wild type astrocytes, as reported in H9c2 cells (Yang et al. 2013). As expected PKC 
activation was not prevented in Pyk2 KO astrocytes, as PKC is thought to be upstream from Pyk2. Interestingly, we also found evidence of increased Rac1 phosphorylation on Ser71 in response to TNF $\alpha$. This phosphorylation which is reported to depend on Akt and to alter GTP binding (Kwon et al. 2000), was also unaltered in Pyk2-deficient astrocytes.

We evaluated other links between Pyk2 and actin dynamics in astrocytes and focused on the putative role of gelsolin, which is increased in injured neural tissue (Zhang et al. 2013). Gelsolin interacts with and is regulated by Pyk2 phosphorylation in osteoclasts, in which it forms actin rings for bone remodeling (Wang et al. 2003). Gelsolin was also observed around the inner edge of actin filaments in moving cells in skin lesions (Cowin et al. 2003). Gelsolin is also necessary for macrophages migration in peripheral nerves injury (Goncalves et al. 2010). Importantly, Pyk2 phosphorylates gelsolin on tyrosine residues (Wang et al. 2003). Gelsolin is activated by intracellular calcium increases (Kronenberg et al. 2010) and can contribute to cell migration (Thompson et al. 2007). In the absence of gelsolin, actin filaments are stabilized and the migration of newborn cells is slowed in the hippocampus (Kronenberg et al. 2010). In our wound healing experiments we observed increased gelsolin immunoreactivity at the leading edge of migrating astrocytes corresponding to lamellipodia. This enrichment was much less pronounced in Pyk2-deficient migrating astrocytes. This result suggests that Pyk2 activation facilitates astrocytes migration by recruiting gelsolin at the leading edge of migrating cells and that impairment of this recruitment contributes to the defect in migration observed in the absence of Pyk2.

In conclusion, our results indicate that after physical brain injury, astrocytes lacking Pyk2 react normally, orientate themselves properly, and display efficient capacities of cell adhesion and proliferation. However, the ability of astrocytes to migrate towards the wound is compromised since the lack of Pyk2 alters actin dynamics, a deficit that could result, at least in part, from a lack of gelsolin recruitment at the leading edge of migrating astrocytes. Thus, our findings provide insights into the role of Pyk2 in glial scar formation. Importantly, Pyk2 has been implicated in the migration of glioma cells (Lipinski et al. 2003; Lipinski et al. 2005; Loftus et al. 2013), a response that involves the TNF pathway (Paulino et al. 2010). Our results in astrocytes provide further clues about the role of Pyk2 in the phenotype of glial-derived tumors and its interest as a therapeutic target. 


\section{ACKNOWLEDGEMENTS}

The work was supported by Fondation pour la recherche sur le cerveau (FRC), Fondation pour la recherche médicale (FRM), and an ERC Advanced investigator grant to JAG. JAG's group is affiliated with the Paris School of Neuroscience and the Bio-Psy Laboratory of Excellence. The authors declare no conflict of interest. 


\section{REFERENCES}

Aoto H, Sasaki H, Ishino M, Sasaki T. 2002. Nuclear translocation of cell adhesion kinase beta/prolinerich tyrosine kinase 2. Cell Struct Funct 27:47-61.

Aroeira RI, Sebastiao AM, Valente CA. 2015. BDNF, via truncated TrkB receptor, modulates GlyT1 and GlyT2 in astrocytes. Glia 63:2181-97.

Avraham H, Park SY, Schinkmann K, Avraham S. 2000. RAFTK/Pyk2-mediated cellular signalling. Cell Signal 12:123-133.

Ben-Ze'ev A. 1997. Cytoskeletal and adhesion proteins as tumor suppressors. Curr Opin Cell Biol 9:99108.

Benveniste EN, Sparacio SM, Bethea JR. 1989. Tumor necrosis factor-alpha enhances interferongamma-mediated class II antigen expression on astrocytes. J Neuroimmunol 25:209-219.

Buckbinder L, Crawford DT, Qi H, Ke HZ, Olson LM, Long KR, Bonnette PC, Baumann AP, Hambor JE, Grasser WA, 3rd, Pan LC, Owen TA, Luzzio MJ, Hulford CA, Gebhard DF, Paralkar VM, Simmons HA, Kath JC, Roberts WG, Smock SL, Guzman-Perez A, Brown TA, Li M. 2007. Proline-rich tyrosine kinase 2 regulates osteoprogenitor cells and bone formation, and offers an anabolic treatment approach for osteoporosis. Proc Natl Acad Sci U S A 104:10619-24.

Bush TG, Puvanachandra N, Horner CH, Polito A, Ostenfeld T, Svendsen CN, Mucke L, Johnson MH, Sofroniew MV. 1999. Leukocyte infiltration, neuronal degeneration, and neurite outgrowth after ablation of scar-forming, reactive astrocytes in adult transgenic mice. Neuron 23:297308.

Castilho RM, Squarize CH, Leelahavanichkul K, Zheng Y, Bugge T, Gutkind JS. 2010. Rac1 is required for epithelial stem cell function during dermal and oral mucosal wound healing but not for tissue homeostasis in mice. PLoS One 5:e10503.

Cazaubon S, Chaverot N, Romero IA, Girault JA, Adamson P, Strosberg AD, Couraud PO. 1997. Growth factor activity of endothelin-1 in primary astrocytes mediated by adhesion-dependent and independent pathways. J Neurosci 17:6203-6212.

Chung CH, Fan J, Lee EY, Kang JS, Lee SJ, Pyagay PE, Khoury CC, Yeo TK, Khayat MF, Wang A, Chen S. 2015. Effects of Tumor Necrosis Factor-alpha on Podocyte Expression of Monocyte Chemoattractant Protein-1 and in Diabetic Nephropathy. Nephron Extra 5:1-18.

Climent E, Sancho-Tello M, Minana R, Barettino D, Guerri C. 2000. Astrocytes in culture express the full-length Trk-B receptor and respond to brain derived neurotrophic factor by changing intracellular calcium levels: effect of ethanol exposure in rats. Neurosci Lett 288:53-6.

Cowin AJ. 2005. Differential expression of F-actin in in utero fetal wounds. Eur J Dermatol 15:133139.

Cowin AJ, Hatzirodos N, Teusner JT, Belford DA. 2003. Differential effect of wounding on actin and its associated proteins, paxillin and gelsolin, in fetal skin explants. J Invest Dermatol 120:11181129.

Deli MA, Descamps L, Dehouck MP, Cecchelli R, Joo F, Abraham CS, Torpier G. 1995. Exposure of tumor necrosis factor-alpha to luminal membrane of bovine brain capillary endothelial cells cocultured with astrocytes induces a delayed increase of permeability and cytoplasmic stress fiber formation of actin. J Neurosci Res 41:717-726.

Desai LP, Aryal AM, Ceacareanu B, Hassid A, Waters CM. 2004. RhoA and Rac1 are both required for efficient wound closure of airway epithelial cells. Am J Physiol Lung Cell Mol Physiol 287:L1134-L1144.

Du QS, Ren XR, Xie Y, Wang Q, Mei L, Xiong WC. 2001. Inhibition of PYK2-induced actin cytoskeleton reorganization, PYK2 autophosphorylation and focal adhesion targeting by FAK. J Cell Sci 114:2977-2987.

Gil-Henn H, Destaing O, Sims NA, Aoki K, Alles N, Neff L, Sanjay A, Bruzzaniti A, De Camilli P, Baron R, Schlessinger J. 2007. Defective microtubule-dependent podosome organization in osteoclasts leads to increased bone density in Pyk2(-/-) mice. J Cell Biol 178:1053-64. 
Giralt A, Friedman HC, Caneda-Ferron B, Urban N, Moreno E, Rubio N, Blanco J, Peterson A, Canals JM, Alberch J. 2010. BDNF regulation under GFAP promoter provides engineered astrocytes as a new approach for long-term protection in Huntington's disease. Gene Ther 17:12941308.

Girault JA, Costa A, Derkinderen P, Studler JM, Toutant M. 1999. FAK and PYK2/CAKbeta in the nervous system: a link between neuronal activity, plasticity and survival? Trends Neurosci 22:257-63.

Goicoechea SM, Arneman D, Otey CA. 2008. The role of palladin in actin organization and cell motility. Eur J Cell Biol 87:517-525.

Goncalves AF, Dias NG, Moransard M, Correia R, Pereira JA, Witke W, Suter U, Relvas JB. 2010. Gelsolin is required for macrophage recruitment during remyelination of the peripheral nervous system. Glia 58:706-715.

Gott AL, Mallon BS, Paton A, Groome N, Rumsby MG. 1994. Rat brain glial cells in primary culture and subculture contain the delta, epsilon and zeta subspecies of protein kinase $C$ as well as the conventional subspecies. Neurosci Lett 171:117-20.

Hampton DW, Rhodes KE, Zhao C, Franklin RJ, Fawcett JW. 2004. The responses of oligodendrocyte precursor cells, astrocytes and microglia to a cortical stab injury, in the brain. Neuroscience 127:813-820.

Holtje M, Hoffmann A, Hofmann F, Mucke C, Grosse G, Van RN, Kettenmann H, Just I, Ahnert-Hilger G. 2005. Role of Rho GTPase in astrocyte morphology and migratory response during in vitro wound healing. J Neurochem 95:1237-1248.

Huang Y, Lu W, Ali DW, Pelkey KA, Pitcher GM, Lu YM, Aoto H, Roder JC, Sasaki T, Salter MW, MacDonald JF. 2001. CAKbeta/Pyk2 kinase is a signaling link for induction of long-term potentiation in CA1 hippocampus. Neuron 29:485-96.

Kaibuchi K, Kuroda S, Amano M. 1999. Regulation of the cytoskeleton and cell adhesion by the Rho family GTPases in mammalian cells. Annu Rev Biochem 68:459-486.

Kamen LA, Schlessinger J, Lowell CA. 2011. Pyk2 is required for neutrophil degranulation and host defense responses to bacterial infection. J Immunol 186:1656-65.

Kinouchi R, Takeda M, Yang L, Wilhelmsson U, Lundkvist A, Pekny M, Chen DF. 2003. Robust neural integration from retinal transplants in mice deficient in GFAP and vimentin. Nat Neurosci 6:863-868.

Koppel AC, Kiss A, Hindes A, Burns CJ, Marmer BL, Goldberg G, Blumenberg M, Efimova T. 2014. Delayed skin wound repair in proline-rich protein tyrosine kinase 2 knockout mice. Am J Physiol Cell Physiol 306:C899-909.

Kronenberg G, Gertz K, Baldinger T, Kirste I, Eckart S, Yildirim F, Ji S, Heuser I, Schrock H, Hortnagl H, Sohr R, Djoufack PC, Juttner R, Glass R, Przesdzing I, Kumar J, Freyer D, Hellweg R, Kettenmann H, Fink KB, Endres M. 2010. Impact of actin filament stabilization on adult hippocampal and olfactory bulb neurogenesis. J Neurosci 30:3419-3431.

Kwon T, Kwon DY, Chun J, Kim JH, Kang SS. 2000. Akt protein kinase inhibits Rac1-GTP binding through phosphorylation at serine 71 of Rac1. J Biol Chem 275:423-8.

Lang D, Glukhov AV, Efimova T, Efimov IR. 2011. Role of Pyk2 in cardiac arrhythmogenesis. Am J Physiol Heart Circ Physiol 301:H975-83.

Lev S, Moreno H, Martinez R, Canoll P, Peles E, Musacchio JM, Plowman GD, Rudy B, Schlessinger J. 1995. Protein tyrosine kinase PYK2 involved in $\mathrm{Ca}(2+)$-induced regulation of ion channel and MAP kinase functions. Nature 376:737-45.

Liang CC, Park AY, Guan JL. 2007. In vitro scratch assay: a convenient and inexpensive method for analysis of cell migration in vitro. Nat Protoc 2:329-333.

Lieberman AP, Pitha PM, Shin HS, Shin ML. 1989. Production of tumor necrosis factor and other cytokines by astrocytes stimulated with lipopolysaccharide or a neurotropic virus. Proc Natl Acad Sci U S A 86:6348-6352.

Lim Y, Lim ST, Tomar A, Gardel M, Bernard-Trifilo JA, Chen XL, Uryu SA, Canete-Soler R, Zhai J, Lin H, Schlaepfer WW, Nalbant P, Bokoch G, llic D, Waterman-Storer C, Schlaepfer DD. 2008. PyK2 
and FAK connections to p190Rho guanine nucleotide exchange factor regulate RhoA activity, focal adhesion formation, and cell motility. J Cell Biol 180:187-203.

Lipinski CA, Tran NL, Bay C, Kloss J, McDonough WS, Beaudry C, Berens ME, Loftus JC. 2003. Differential role of proline-rich tyrosine kinase 2 and focal adhesion kinase in determining glioblastoma migration and proliferation. Mol Cancer Res 1:323-332.

Lipinski CA, Tran NL, Menashi E, Rohl C, Kloss J, Bay RC, Berens ME, Loftus JC. 2005. The tyrosine kinase pyk2 promotes migration and invasion of glioma cells. Neoplasia 7:435-445.

Loftus JC, Yang Z, Kloss J, Dhruv H, Tran NL, Riggs DL. 2013. A Novel Interaction between Pyk2 and MAP4K4 Is Integrated with Glioma Cell Migration. J Signal Transduct 2013:956580.

Lu M, Witke W, Kwiatkowski DJ, Kosik KS. 1997. Delayed retraction of filopodia in gelsolin null mice. J Cell Biol 138:1279-1287.

Mburu P, Romero MR, Hilton H, Parker A, Townsend S, Kikkawa Y, Brown SD. 2010. Gelsolin plays a role in the actin polymerization complex of hair cell stereocilia. PLoS One 5:e11627.

McGraw J, Hiebert GW, Steeves JD. 2001. Modulating astrogliosis after neurotrauma. J Neurosci Res 63:109-115.

Menegon A, Burgaya F, Baudot P, Dunlap DD, Girault JA, Valtorta F. 1999. FAK+ and PYK2/CAKbeta, two related tyrosine kinases highly expressed in the central nervous system: similarities and differences in the expression pattern. Eur J Neurosci 11:3777-3788.

Meng XQ, Zheng KG, Yang Y, Jiang MX, Zhang YL, Sun QY, Li YL. 2006. Proline-rich tyrosine kinase2 is involved in F-actin organization during in vitro maturation of rat oocyte. Reproduction 132:859-867.

Mitsushima M, Takahashi H, Shishido T, Ueda K, Kioka N. 2006. Abl kinase interacts with and phosphorylates vinexin. FEBS Lett 580:4288-4295.

Muller G, Ayoub M, Storz P, Rennecke J, Fabbro D, Pfizenmaier K. 1995. PKC zeta is a molecular switch in signal transduction of TNF-alpha, bifunctionally regulated by ceramide and arachidonic acid. EMBO J 14:1961-9.

Murasawa S, Matsubara H, Mori Y, Masaki H, Tsutsumi Y, Shibasaki Y, Kitabayashi I, Tanaka Y, Fujiyama S, Koyama Y, Fujiyama A, Iba S, Iwasaka T. 2000. Angiotensin II initiates tyrosine kinase Pyk2-dependent signalings leading to activation of Rac1-mediated c-Jun NH2-terminal kinase. J Biol Chem 275:26856-26863.

Nagaoka K, Udagawa T, Richter JD. 2012. CPEB-mediated ZO-1 mRNA localization is required for epithelial tight-junction assembly and cell polarity. Nat Commun 3:675.

Norris JG, Tang LP, Sparacio SM, Benveniste EN. 1994. Signal transduction pathways mediating astrocyte IL-6 induction by IL-1 beta and tumor necrosis factor-alpha. J Immunol 152:841-50.

Okigaki M, Davis C, Falasca M, Harroch S, Felsenfeld DP, Sheetz MP, Schlessinger J. 2003. Pyk2 regulates multiple signaling events crucial for macrophage morphology and migration. Proc Natl Acad Sci U S A 100:10740-10745.

Ovcharenko A, Granot G, Rokah OH, Park J, Shpilberg O, Raanani P. 2013. Enhanced adhesion/migration and induction of Pyk2 expression in $\mathrm{K} 562$ cells following imatinib exposure. Leuk Res 37:1729-1736.

Paulino VM, Yang Z, Kloss J, Ennis MJ, Armstrong BA, Loftus JC, Tran NL. 2010. TROY (TNFRSF19) is overexpressed in advanced glial tumors and promotes glioblastoma cell invasion via Pyk2Rac1 signaling. Mol Cancer Res 8:1558-1567.

Pekny M, Nilsson M. 2005. Astrocyte activation and reactive gliosis. Glia 50:427-434.

Raponi E, Agenes F, Delphin C, Assard N, Baudier J, Legraverend C, Deloulme JC. 2007. S100B expression defines a state in which GFAP-expressing cells lose their neural stem cell potential and acquire a more mature developmental stage. Glia 55:165-77.

Ren XR, Du QS, Huang YZ, Ao SZ, Mei L, Xiong WC. 2001. Regulation of CDC42 GTPase by proline-rich tyrosine kinase 2 interacting with PSGAP, a novel pleckstrin homology and Src homology 3 domain containing rhoGAP protein. J Cell Biol 152:971-984.

Ridley AJ, Schwartz MA, Burridge K, Firtel RA, Ginsberg MH, Borisy G, Parsons JT, Horwitz AR. 2003. Cell migration: integrating signals from front to back. Science 302:1704-1709. 
Rose CR, Blum R, Pichler B, Lepier A, Kafitz KW, Konnerth A. 2003. Truncated TrkB-T1 mediates neurotrophin-evoked calcium signalling in glia cells. Nature 426:74-8.

Saadoun S, Papadopoulos MC, Watanabe H, Yan D, Manley GT, Verkman AS. 2005. Involvement of aquaporin-4 in astroglial cell migration and glial scar formation. J Cell Sci 118:5691-5698.

Santello M, Bezzi P, Volterra A. 2011. TNFalpha controls glutamatergic gliotransmission in the hippocampal dentate gyrus. Neuron 69:988-1001.

Sasaki H, Nagura K, Ishino M, Tobioka H, Kotani K, Sasaki T. 1995. Cloning and characterization of cell adhesion kinase beta, a novel protein-tyrosine kinase of the focal adhesion kinase subfamily. J Biol Chem 270:21206-19.

Sholl DA. 1953. Dendritic organization in the neurons of the visual and motor cortices of the cat. J Anat 87:387-406.

Siciliano JC, Toutant M, Derkinderen P, Sasaki T, Girault JA. 1996. Differential regulation of prolinerich tyrosine kinase 2/cell adhesion kinase beta (PYK2/CAKbeta) and pp125(FAK) by glutamate and depolarization in rat hippocampus. J Biol Chem 271:28942-6.

Sieg DJ, Ilic D, Jones KC, Damsky CH, Hunter T, Schlaepfer DD. 1998. Pyk2 and Src-family proteintyrosine kinases compensate for the loss of FAK in fibronectin-stimulated signaling events but Pyk2 does not fully function to enhance FAK- cell migration. EMBO J 17:5933-47.

Su Z, Yuan Y, Chen J, Cao L, Zhu Y, Gao L, Qiu Y, He C. 2009. Reactive astrocytes in glial scar attract olfactory ensheathing cells migration by secreted TNF-alpha in spinal cord lesion of rat. PLoS One 4:e8141.

Sullivan SM, Bjorkman ST, Miller SM, Colditz PB, Pow DV. 2010. Structural remodeling of gray matter astrocytes in the neonatal pig brain after hypoxia/ischemia. Glia 58:181-94.

Tchelingerian JL, Le SF, Jacque C. 1996. Identification and topography of neuronal cell populations expressing TNF alpha and IL-1 alpha in response to hippocampal lesion. J Neurosci Res 43:99106.

Thompson CC, Ashcroft FJ, Patel S, Saraga G, Vimalachandran D, Prime W, Campbell F, Dodson A, Jenkins RE, Lemoine NR, Crnogorac-Jurcevic T, Yin HL, Costello E. 2007. Pancreatic cancer cells overexpress gelsolin family-capping proteins, which contribute to their cell motility. Gut 56:95-106.

Tomar A, Schlaepfer DD. 2009. Focal adhesion kinase: switching between GAPs and GEFs in the regulation of cell motility. Curr Opin Cell Biol 21:676-683.

Tomas M, Lazaro-Dieguez F, Duran JM, Marin P, Renau-Piqueras J, Egea G. 2003. Protective effects of lysophosphatidic acid (LPA) on chronic ethanol-induced injuries to the cytoskeleton and on glucose uptake in rat astrocytes. J Neurochem 87:220-229.

Wang K, Bekar LK, Furber K, Walz W. 2004. Vimentin-expressing proximal reactive astrocytes correlate with migration rather than proliferation following focal brain injury. Brain Res 1024:193-202.

Wang Q, Xie Y, Du QS, Wu XJ, Feng X, Mei L, McDonald JM, Xiong WC. 2003. Regulation of the formation of osteoclastic actin rings by proline-rich tyrosine kinase 2 interacting with gelsolin. J Cell Biol 160:565-575.

Witke W, Sharpe AH, Hartwig JH, Azuma T, Stossel TP, Kwiatkowski DJ. 1995. Hemostatic, inflammatory, and fibroblast responses are blunted in mice lacking gelsolin. Cell 81:41-51.

Yang CM, Lee IT, Hsu RC, Chi PL, Hsiao LD. 2013. NADPH oxidase/ROS-dependent PYK2 activation is involved in TNF-alpha-induced matrix metalloproteinase-9 expression in rat heart-derived H9c2 cells. Toxicol Appl Pharmacol 272:431-442.

Ying Z, Giachini FR, Tostes RC, Webb RC. 2009. PYK2/PDZ-RhoGEF links Ca2+ signaling to RhoA. Arterioscler Thromb Vasc Biol 29:1657-1663.

Yuan Z, Yao F, Hu Z, Sun S, Wu B. 2015. Quercetin inhibits the migration and proliferation of astrocytes in wound healing. Neuroreport 26:387-393.

Zhang QH, Li JC, Dong N, Tang LM, Zhu XM, Sheng ZY, Yao YM. 2013. Burn injury induces gelsolin expression and cleavage in the brain of mice. Neuroscience 228:60-72. 


\section{FIGURE LEGENDS}

FIGURE 1. Generation and characterization of Pyk2 knockout mice. (A) Strategy used to knock out the Pyk2 gene. Hatched rectangles, Pyk2 coding sequences; grey rectangles, noncoding exon portions; solid lines, chromosome sequences; triangles, LoxP sites; double triangles, FRT sites. (B) Representative mice from each genotype $\left(\mathrm{Pyk}^{+/+}, \mathrm{Pyk}^{+/-}\right.$, and $\mathrm{Pyk} 2^{-/-}$ ). (C) Immunoblots of hippocampal homogenates probed with antibodies for phosphoTyr402-Pyk2 (pY402-Pyk2), Pyk2, and $\alpha$-tubulin. (D-E) Quantification by densitometric analysis of immunoblots as in (C) showing the levels of phosphoTyr402-Pyk2 (D) and Pyk2 (E) in mice from the 3 genotypes. Bars are means \pm s.e.m. and individual points each corresponding to a mouse are indicated (5-4 per group). Statistical analysis one-way $\operatorname{ANOVA}\left(D, F_{(2,11)}=26.27, p<0.001 ; E, F_{(2,11)}=169, p<0.001\right)$ and post hoc Tukey's test $(* * *$ p <0.001). No signal was detected in homozygous mutant mice. (F) Pyk2 immunofluorescence in brain slices from $\mathrm{Pyk2}^{+/+}, \mathrm{Pyk2}^{+/-}$, and Pyk2 ${ }^{-/-}$mice. (G) Nissl stained sections showed no gross anatomy deficiencies in $\mathrm{Pyk} 2^{-/-}$or in $\mathrm{Pyk} 2^{+/-}$compared to $\mathrm{Pyk} 2^{+/+}$mice. Scale bars, 1 $\mathrm{mm}$. (H) GFAP-immunostained astrocyte in the cortex of a wild type (left panel) and Pyk2-/mouse (right panel). Scale bar, $200 \mu \mathrm{m}$. (I) Sholl analysis of astrocytes ramifications in the two genotypes. Data are means + SEM from 30 astrocytes from 3 different mice per genotype. Two-way ANOVA effect of distance from soma, $F_{(6,406)}=171.0, p<0.0001$, no effect of genotype, $F_{(1,406)}=0.10, p=0.75$, no interaction, $F_{(6,406)}=1.54, p=0.16$.

FIGURE 2. Astrocytes Pyk2 expression and migration after stab injury. (A) Brain sections from a wild type mouse were co-immunolabeled for GFAP (red) and Pyk2 (green). Left panel, low magnification, scale bar, $20 \mu \mathrm{m}$. Right panels, higher magnification, scale bar $2 \mu \mathrm{m}$. An astrocyte ramification identified by GFAP immunoreactivity and immunoreactive for Pyk2 is indicated by arrowheads. (B) Brain sections were immunolabeled for GFAP 3 days after a cortical stab lesion in $\mathrm{Pyk}^{+/+}, \mathrm{Pyk}^{+/-}$, and $\mathrm{Pyk}^{-/-}$mice. Stab lesion area is indicated with a dashed line. Scale bar, $150 \mu \mathrm{m}$. (C) Quantification of the area of the GFAP-negative zone. (D) Higher magnification to show astrocytes orientation. White arrows indicate the direction of the wound. Scale bar, $25 \mu \mathrm{m}$. (E) Quantification of astrocytes oriented towards the wound. (F) Quantification of the GFAP-positive area. (C, E, F) Bars represent means \pm s.e.m. (4-7 mice 
per group). Statistical analysis one-way ANOVA $\left(C, F_{(2,16)}=10.33, p=0.0013 ; E, F_{(2,13)}=0.76\right.$, $\left.\mathrm{p}=0.48 ; \mathrm{F}, \mathrm{F}_{(2,14)}=0.055, \mathrm{p}=0.94\right)$ and post-hoc Tukey's test, $\left.* * \mathrm{p}<0.01\right)$.

FIGURE 3. Characterization of $\mathrm{Pyk2}^{+/+}$and $\mathrm{Pyk2}^{-/-}$astrocytes in culture. (A, B) Confluent $\mathrm{Pyk}^{+/+}$and $\mathrm{Pyk}^{-/-}$astrocytes cultures showing similar morphology by phase-contrast microscopy (A) and GFAP immunofluorescence (B, in green, DAPI in blue). Scale bars (A) 90 $\mu \mathrm{m}$, (B) $20 \mu \mathrm{m}$. (C) $\mathrm{Pyk2}^{+/+}$and $\mathrm{Pyk2}^{-/-}$astrocytes were immunostained for Pyk2 and counterstained with rhodamine-phalloidin (an F-actin marker) and DAPI. Scale bar $20 \mu \mathrm{m}$. (D) GFAP, S100B, and TrkB (full length, FL, truncated form, T1) were measured by immunoblotting in astrocytes in culture from wild type and Pyk2 knockout mice, as well as atubulin as a loading control. Molecular weight standards positions are indicated (kDa). (E) Quantification of results as in $(\mathrm{J})$ in each sample the amount of protein was normalized to the amount of $\alpha$-tubulin. Individual data points are shown with means $\pm S E M ; P y k 2+/+, n=5$ mice, $-/-, \mathrm{n}=7$ mice; GFAP, $\mathrm{t}_{10}=0.012, \mathrm{p}=0.99, \mathrm{~S} 100 \mathrm{~B}, \mathrm{t}_{10}=1.57, \mathrm{p}=0.14, \operatorname{TrkB}, \mathrm{t}_{10}=0.95, \mathrm{p}=$ 0.36. (F) Proliferation of $\mathrm{Pyk}^{+/+}$and $\mathrm{Pyk} 2^{-/-}$astrocytes. Cells were counted (8-9 wells per time point) on alternate days after plating $2.8 \times 10^{4}$ astroglia/ $/ \mathrm{cm}^{2}$. Statistical analysis, twoway ANOVA, $F_{(1,10)}=2.174, p=0.17$. (G) Percentage of astroglia adhering to poly-D-lysine 4 hours after plating (8-9 wells per genotype). Bars represent mean \pm s.e.m. and individual points corresponding to each independent culture are shown. Statistical analysis, Student's t-test, $p=0.483$.

FIGURE 4. Astrocytes migration in an in vitro wound healing paradigm. (A) Confluent $\mathrm{Pyk2}^{+/+}$and $\mathrm{Pyk2}^{-/-}$astrocytes cultures were scratched to mimic injury and subsequent wound healing by migrating astrocytes was monitored for up to $48 \mathrm{~h}$. Representative images from phalloidin-labeled astrocytes in the wound tract are shown at 0,24 , and $48 \mathrm{~h}$ postscratching. Scale bar $100 \mu \mathrm{m}$. (B) Quantification of the re-colonization of wounded area by $\mathrm{Pyk2}^{+/+}$and $\mathrm{Pyk}^{-/-}$migrating astrocytes at 0,24 , and $48 \mathrm{~h}$ after scratching (8-12 wells per genotype for each time point; 4 images per well). Black dots: Pyk2 ${ }^{+/+}$astrocytes. White dots: Pyk $^{-/-}$astrocytes. Points are means \pm s.e.m. Statistical analysis, two-way ANOVA, genotype effect, $F_{(1,24)}=4.427, p<0.05$, time effect, $F_{(2,24)}=63.92$, $p<0.001$, interaction, $F_{(2,24)}=3.954$, $\mathrm{p}=0.033$. Post_hoc Sidak's test, ${ }^{*}, \mathrm{p}<0.05$. 
FIGURE 5. Role of Pyk2 in actin re-polymerization after latrunculin B treatment. (A) $\mathrm{Pyk} 2^{+/+}$ and $\mathrm{Pyk}^{-/-}$astrocytes cultures at $50-60 \%$ confluence were treated with $1 \mu \mathrm{M}$ latrunculin $\mathrm{B}$ for $45 \mathrm{~min}$ and then washed with NM-15 medium and allowed to recover for various times before fixation and rhodamine-phalloidin staining. Representative images of phalloidinlabeled astrocytes before latrunculin B treatment $(-45 \mathrm{~min})$, at the end of latrunculin B application (0 min), and $60 \mathrm{~min}$ after washing latrunculin B (60 min). Scale bar $100 \mu \mathrm{m}$. (B) Re-polymerization rate was quantified in experiments as in $(A)$, by measuring the phalloidinpositive cellular area at $-45,0,15$, and 60 min time points as defined above (6-10 wells per genotype for each time point; 4 images per well). Black arrow indicates the end of the latrunculin B treatment. Black dots: Pyk $2^{+/+}$astrocytes. White dots: Pyk2 ${ }^{-/-}$astrocytes. Points are means \pm s.e.m. Statistical analysis for recovery after latrunculin B was done for 0,15 and 60 min with two-way ANOVA. Time effect, $F_{(2,18)}=104.4, p<0.0001$, genotype effect, $F_{(1,18)}=$ 40.97, $p<0.0001$, interaction, $\mathrm{F}_{(2,18)}=10.22, \mathrm{p}=0.0011$. Post-hoc Sidak's test, $* * *, p<0.001$, $* * * *, \mathrm{p}<0.0001$.

FIGURE 6. Signaling pathways activated in astrocytes following treatment with TNF $\alpha$. Confluent Pyk2 ${ }^{+/+}$and Pyk2 $2^{-/}$astrocytes cultures were treated with vehicle (Veh.) for 15 min or TNFa $(10 \mathrm{ng} / \mathrm{ml})$ for $15 \mathrm{~min}$ or $60 \mathrm{~min}$ before lysis. Samples were analyzed by immunoblotting with the indicated antibodies. (A) Immunoblotting for pTyr402-Pyk2, total Pyk2, and $\alpha$-tubulin as a loading control. Molecular weight marker positions are indicated on the right (kDa). (B) Quantification of results as in (A) for wild type astrocytes. (C) Immunoblotting for PKC phospho-substrates, total PKC $\zeta$, and $\alpha$-tubulin as a loading control. (D) Quantification of results as in (C). (E) Immunoblot for pSer71-Rac1/Cdc42, total Rac1, and a-tubulin. (F) Quantification of results as in (E). Black dots: Pyk2 ${ }^{+/+}$astrocytes. White dots: Pyk2 $\%$ astrocytes. (B, D, F) Bars represent means \pm s.e.m. and individual experimental points are indicted ( $n=4-5$ culture for each treatment and genotype). Statistical analysis one-way ANOVA: B, $F_{(2,9)}=5.53, p<0.05$; D left, Pyk2 ${ }^{+/+}, F_{(2,9)}=4.76, p<0.05 ;$ D right, Pyk2 ${ }^{-/-}, F_{(2,9)}=$ 4.42, $p<0.05 ; \mathrm{F}$ left, Pyk2 ${ }^{+/+}, F_{(2,9)}=6.66, p<0.05 ; F$ right, Pyk2 ${ }^{-/}, F_{(2,14)}=5.07, p<0.05$. Post hoc Tukey's test, *, p<0.05.

FIGURE 7. Gelsolin recruitment to the leading edge of migrating astrocytes is decreased in the absence of Pyk2. Confluent $\mathrm{Pyk}^{+/+}$and $\mathrm{Pyk}^{-/-}$astrocytes cultures were scratched to 
mimic injury and gelsolin distribution at the lamellipodia leading edge of migrating astrocytes was monitored at $24 \mathrm{~h}$. (A) Leading edge of a rhodamine-phalloidin- and Pyk2labeled migrating $\mathrm{Pyk}^{+/+}$astrocytes. The white arrow indicates the direction towards the wound and yellow arrows show the leading edge. (B) Gelsolin immunofluorescence at the leading edge of $\mathrm{Pyk2}^{+/+}$(top panels) and Pyk2 ${ }^{-/-}$(bottom panels) migrating astrocytes. Insets show a 3D representation of the distribution of gelsolin immunostaining and its intensity in the area indicated by a rectangle in the left panels. In A and B, scale bars, $5 \mu \mathrm{m}$. (C, D) Quantification of the gelsolin-positive area (C) and mean intensity of gelsolin immunoreactivity (D) at leading edges of migrating Pyk $2^{+/+}$and Pyk2 ${ }^{-/}$astrocytes as in B (25 cells from 5 different wells per genotype). (E) Gelsolin and $\alpha$-tubulin (loading control) levels were measured by immunoblot in total lysates from confluent Pyk2 ${ }^{+/+}$and Pyk2 $2^{-/-}$astrocyte cultures. (F) Quantification of gelsolin levels in experiments as in $E, n=6-7$ per genotype. (C) D, F) Bars represent means \pm s.e.m. and individual experimental points are shown. Statistical analysis Student's t-test: (C), $\mathrm{t}=0.039,(\mathrm{D}), \mathrm{t}=0.001,(\mathrm{E}), \mathrm{t}=0.88 .{ }^{* *} \mathrm{p}<0.01,{ }^{* * *} \mathrm{p}<0.001$. 
Figure 1

A

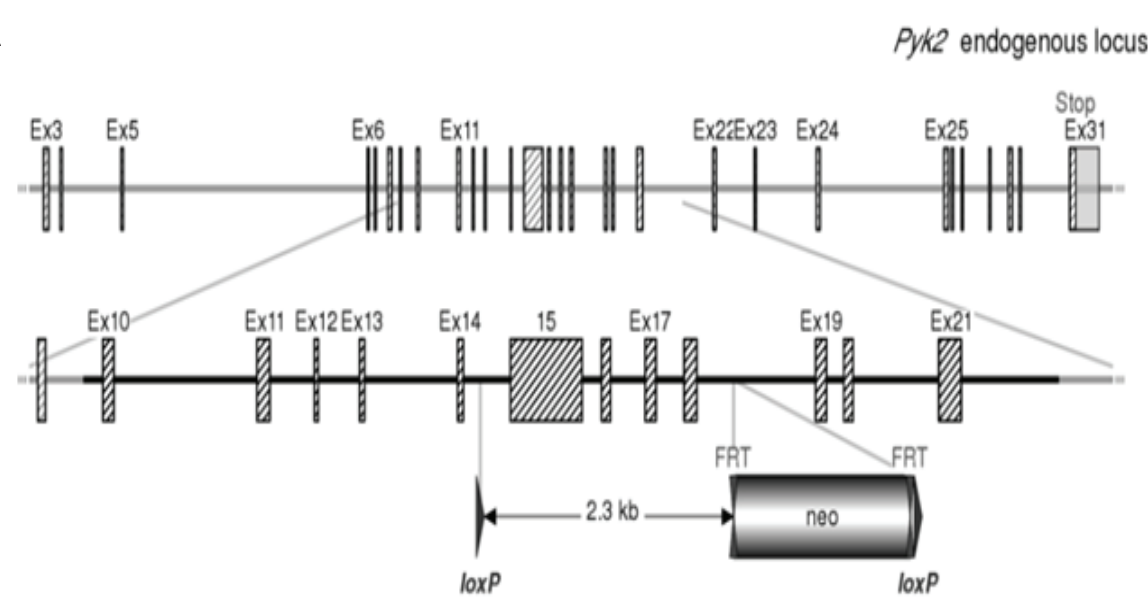

C

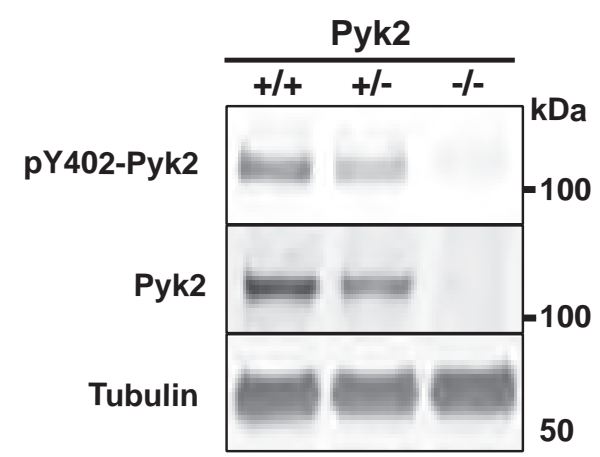

D

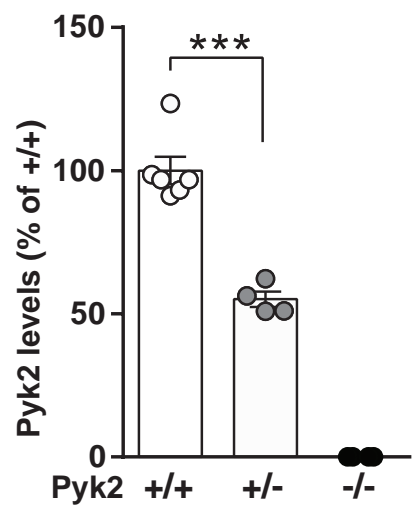

F

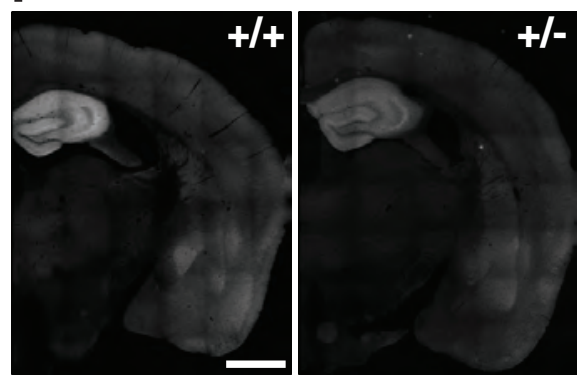

H

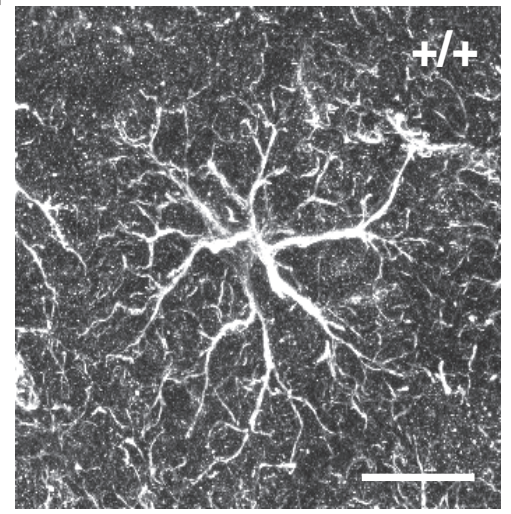

G
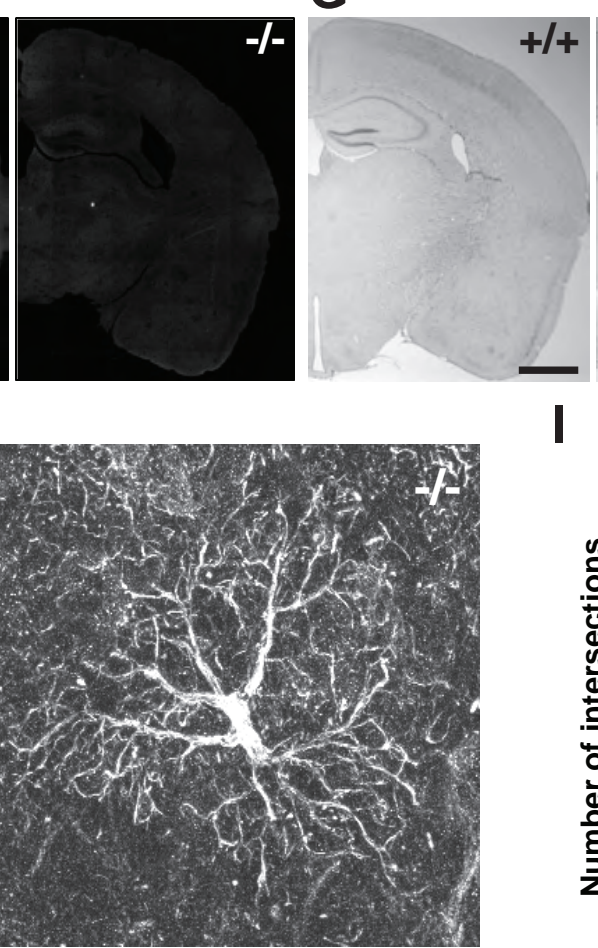

B

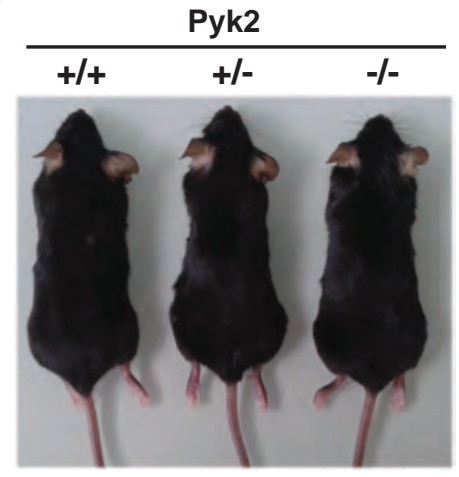

E

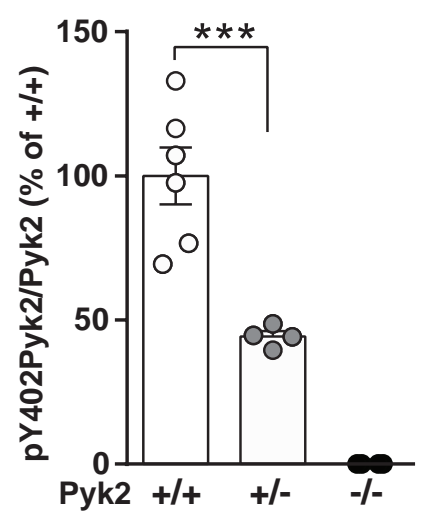

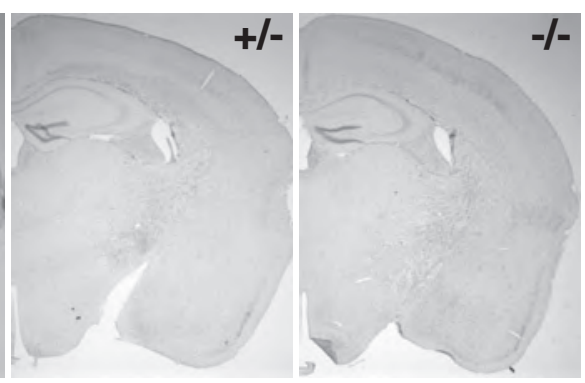

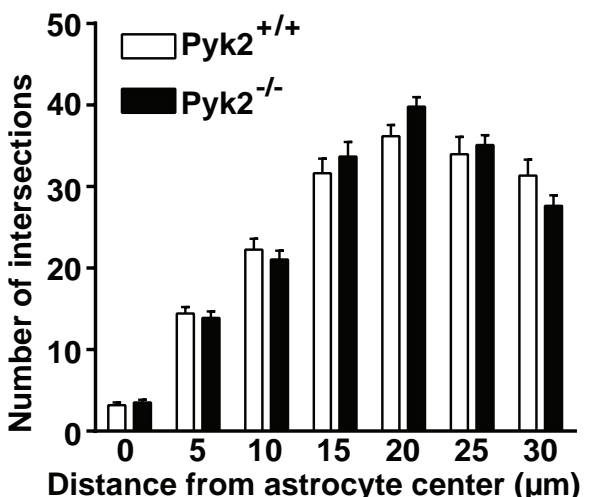


Figure 2

A
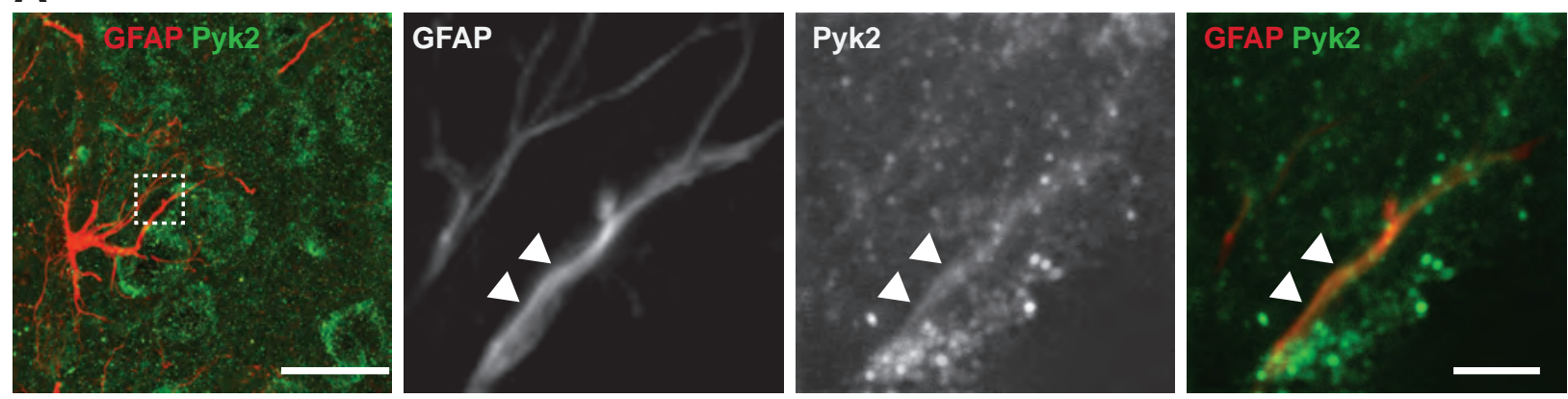

B
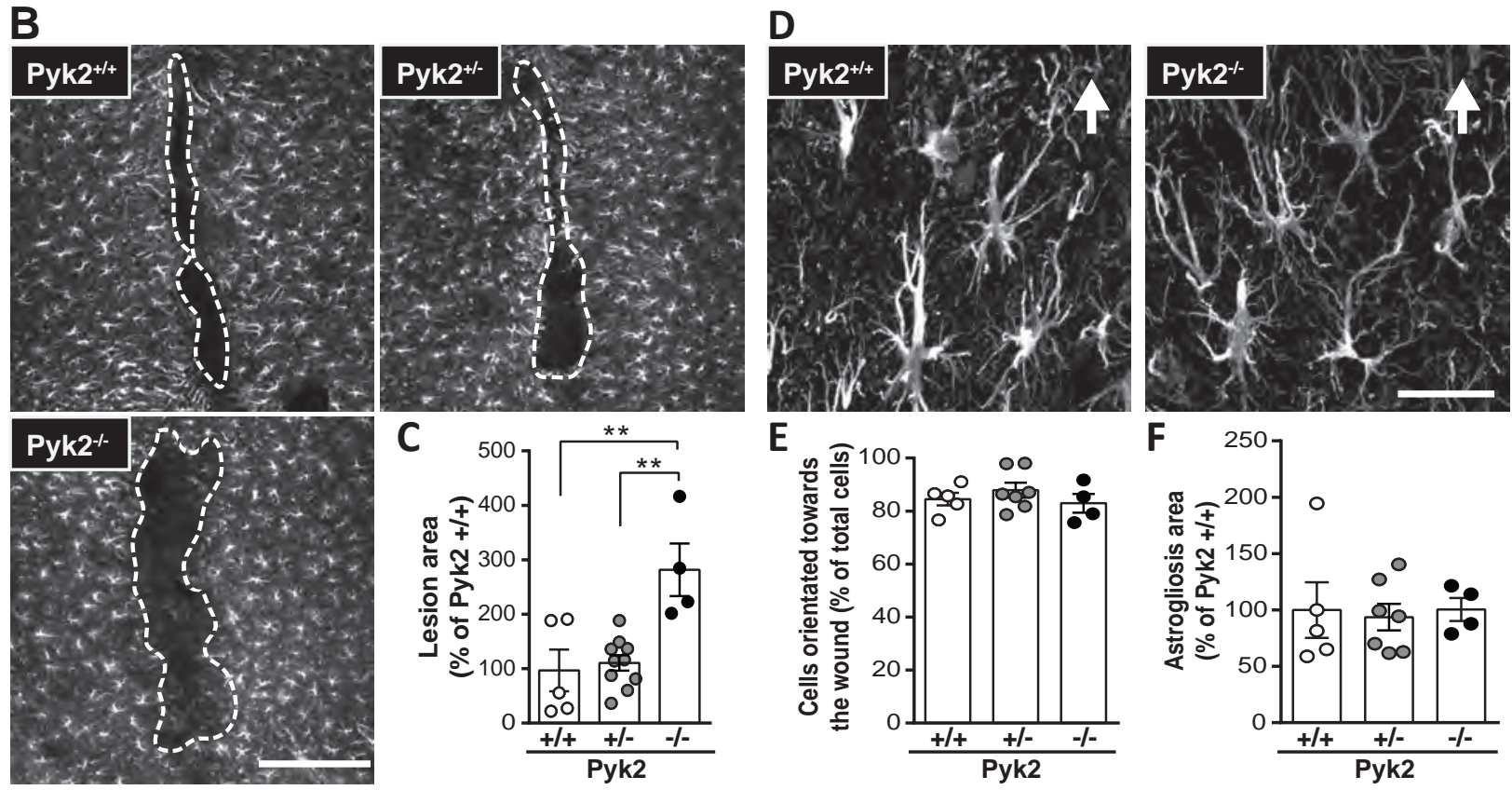
Figure 3

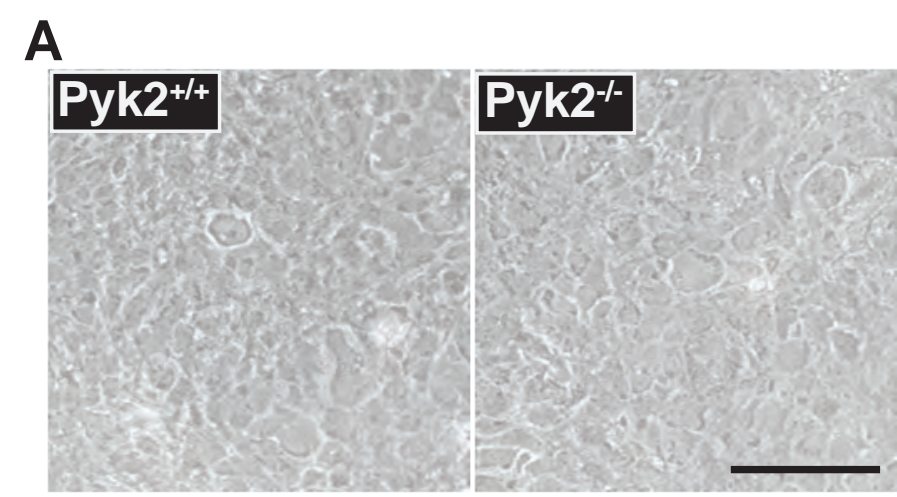

C
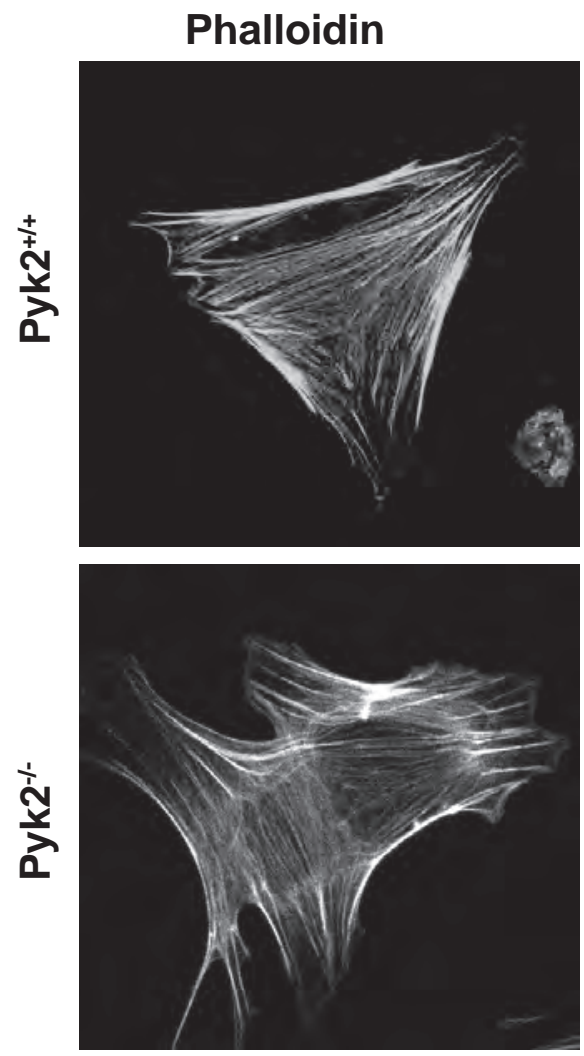

D

kDa

50 -
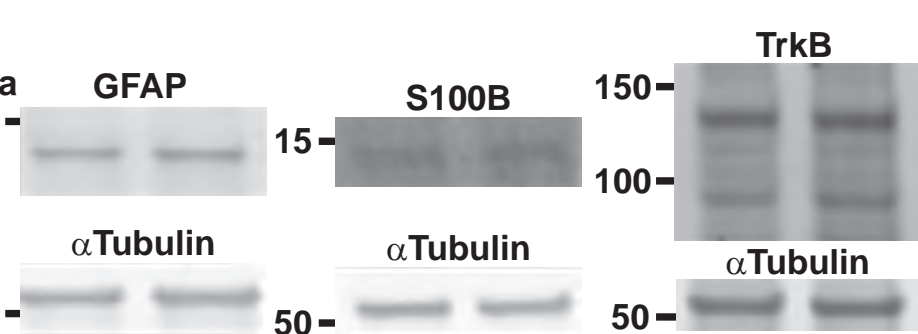

F

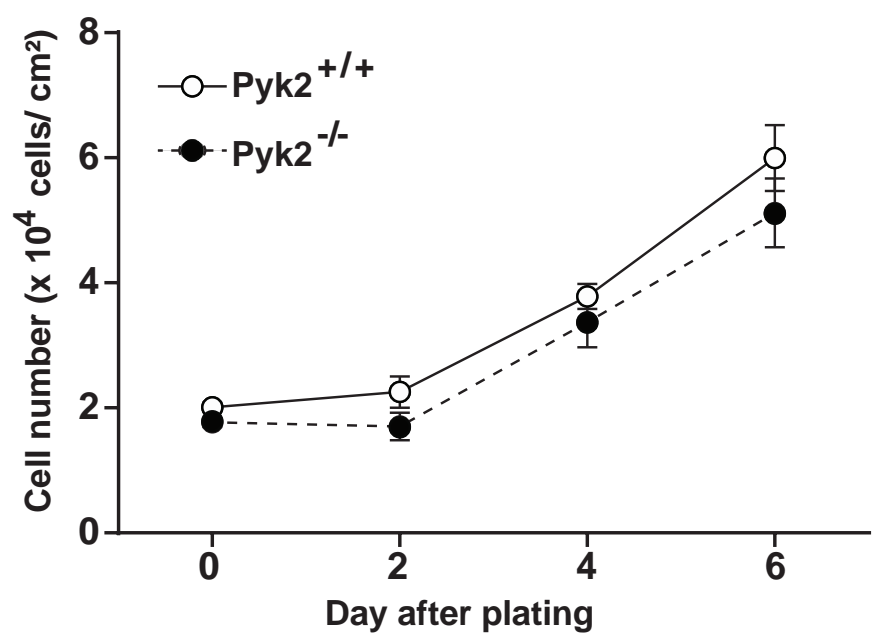

B
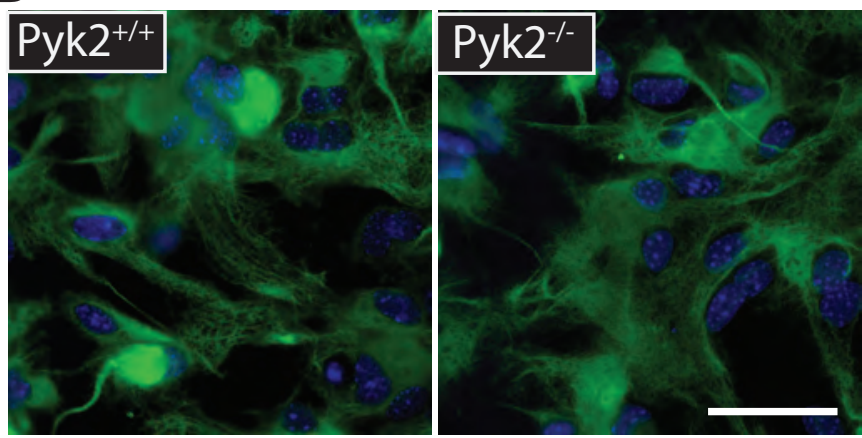

Pyk2

Phalloidin Pyk2 DAPI
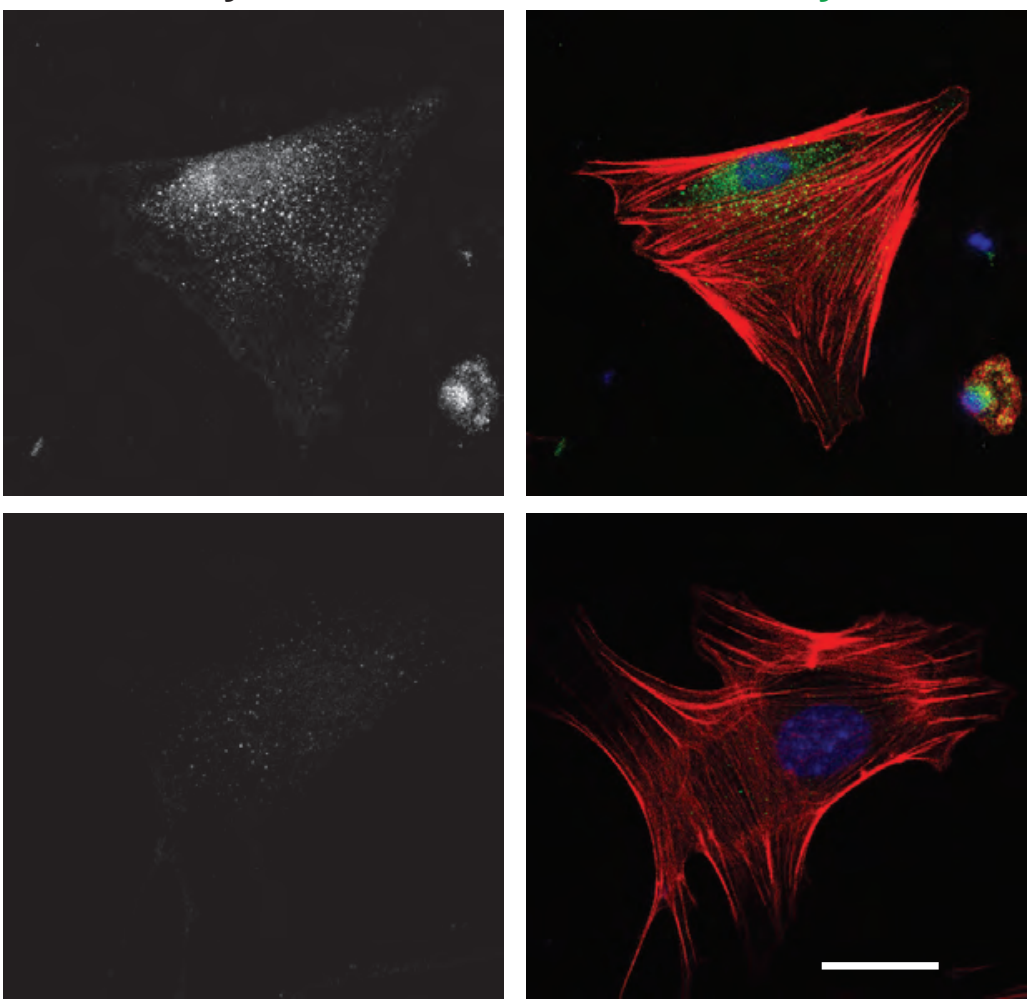

4FL

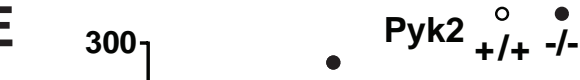

G

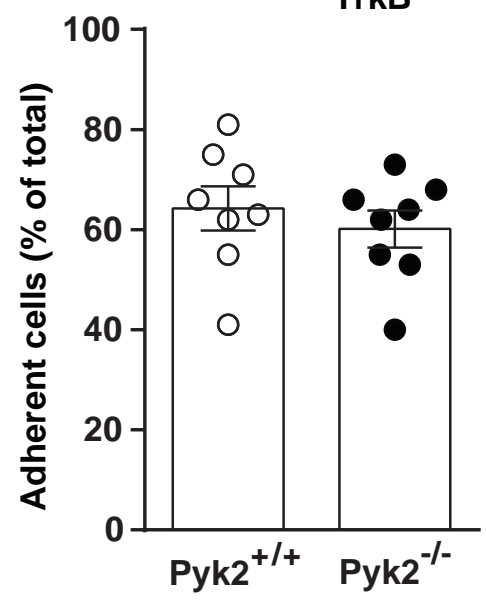


Figure 4
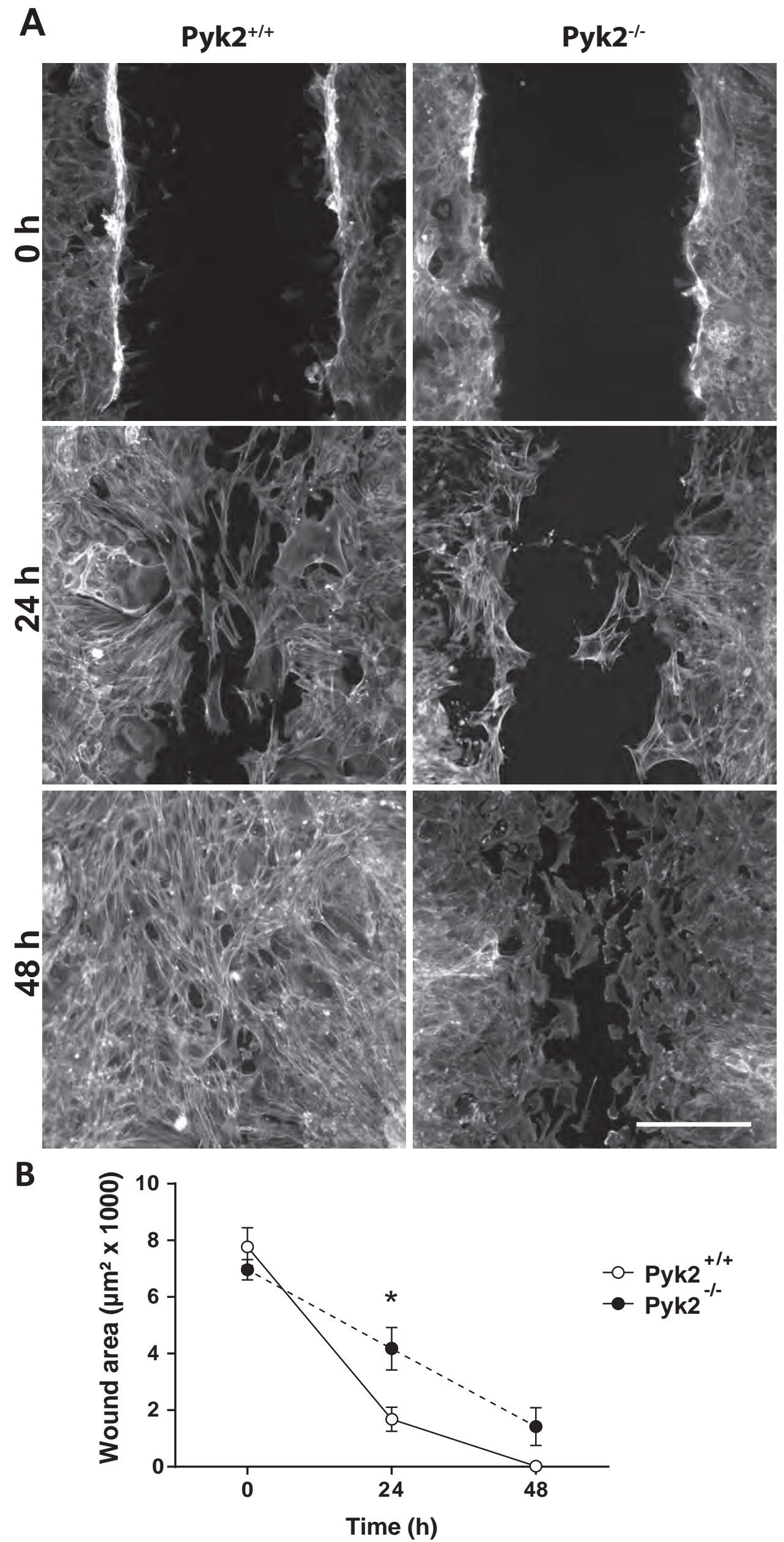
Figure 5

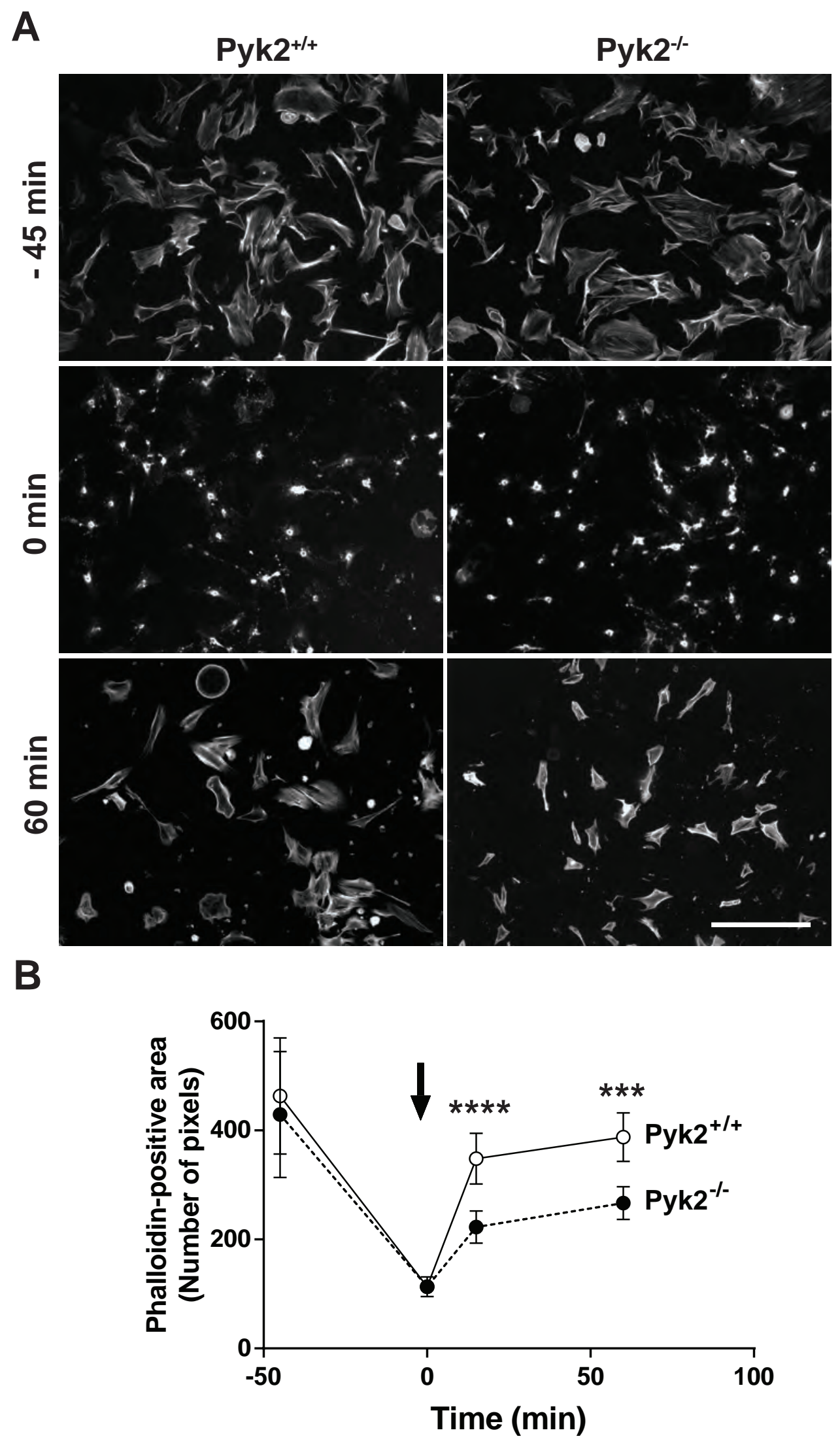


Figure 6

A

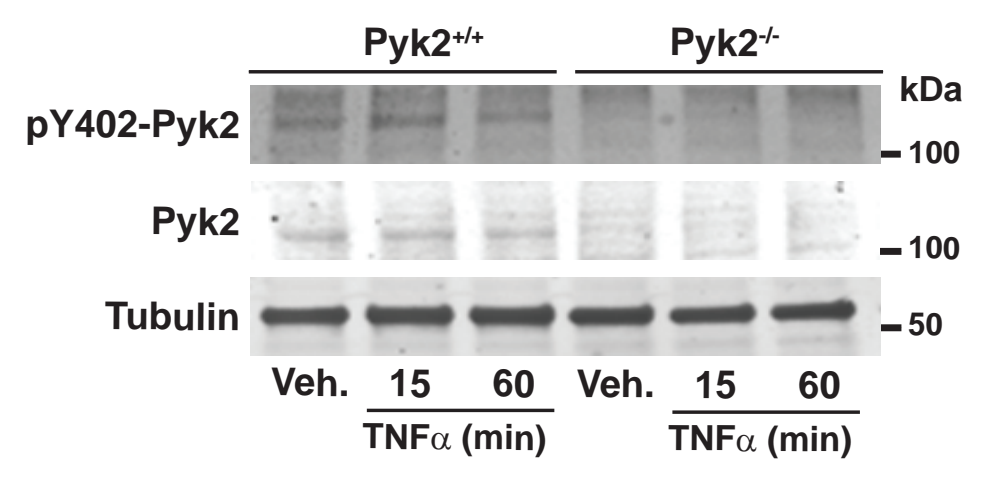

C

phosphosubstrates

E

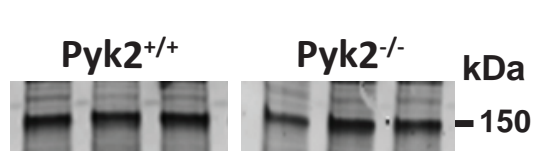

PKC
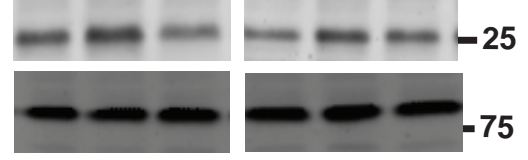

Tubulin

Veh. 1560 Veh. 1560

$\mathrm{TNF} \alpha(\min ) \quad \overline{\operatorname{TNF} \alpha(\min )}$

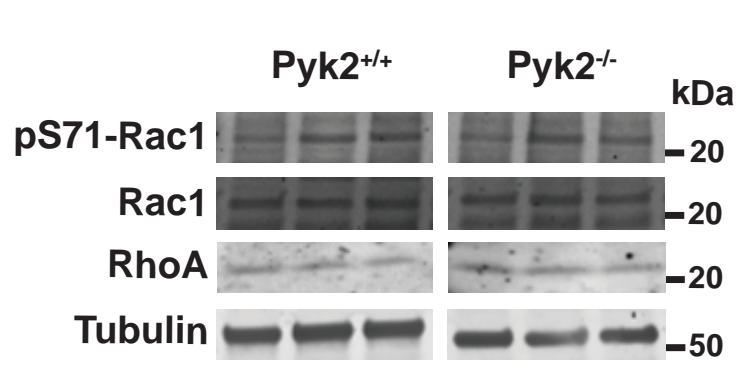

Veh. 1560 Veh. 1560 $\mathrm{TNF} \alpha$ (min) $\quad \overline{N F \alpha ~(m i n)}$
B

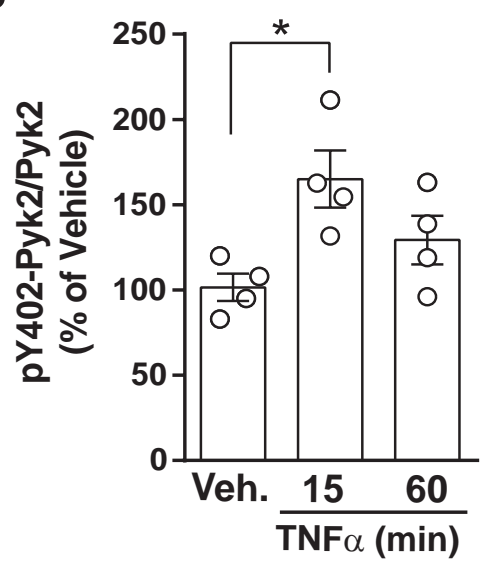

Pyk2 $^{+/+}$

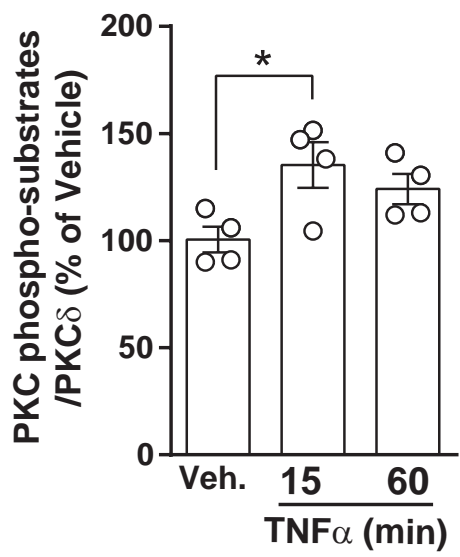

$\mathbf{F}$

Pyk2 $^{+1+}$

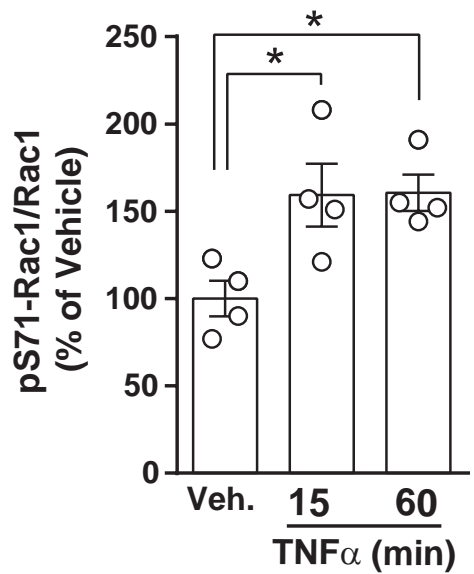

Pyk2

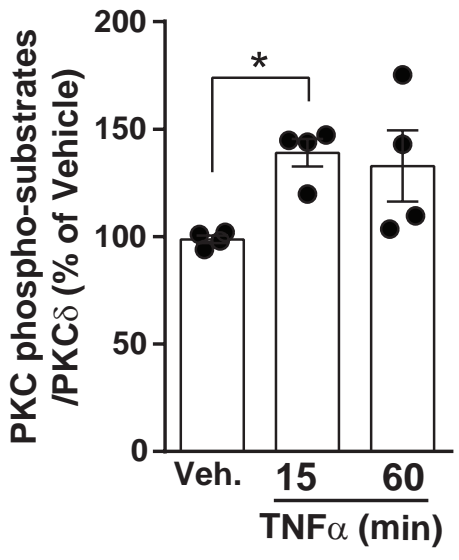

Pyk2

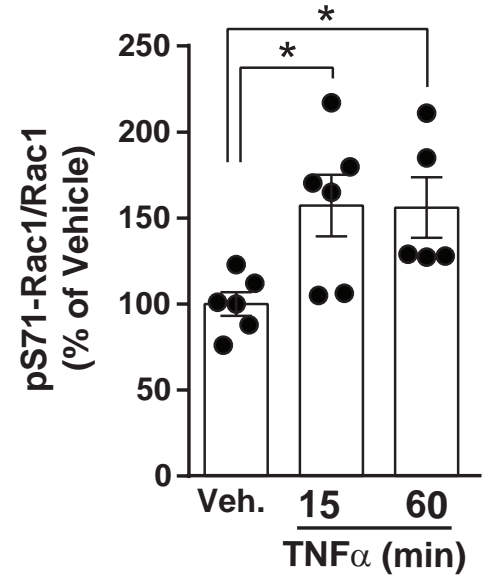


Figure 7

A

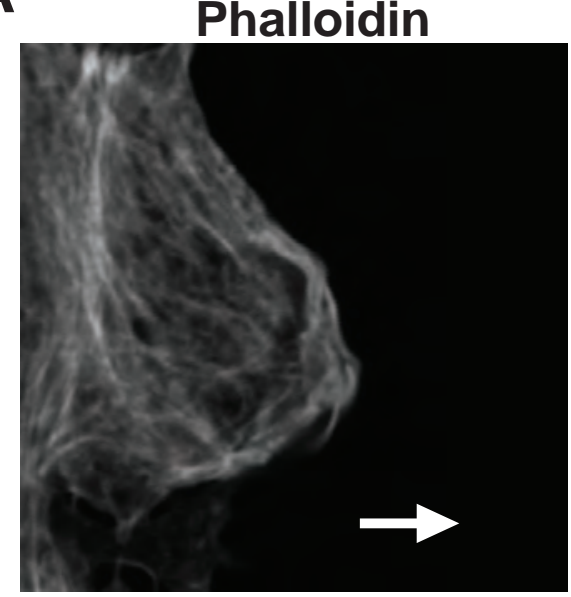

\section{B Gelsolin}
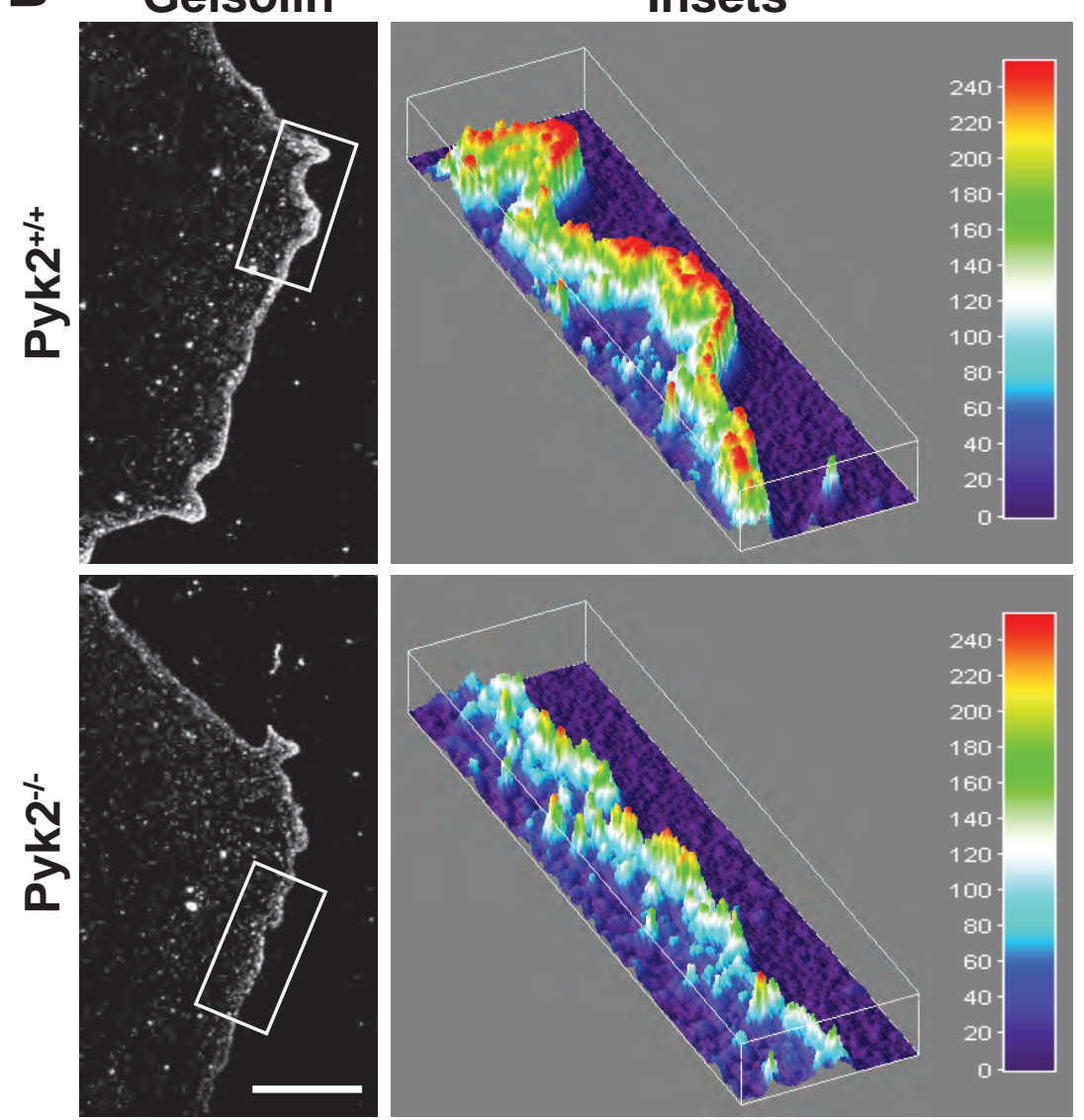

E

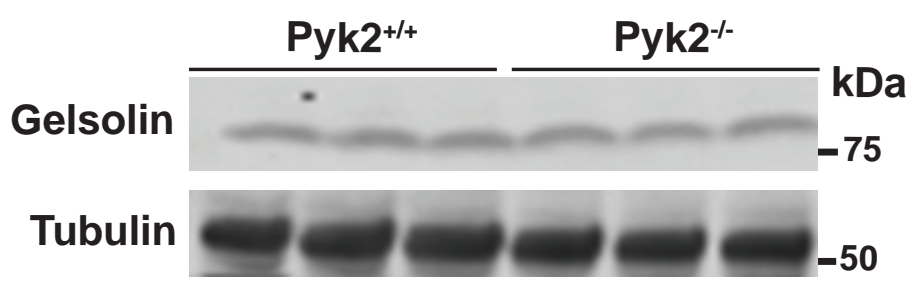

Pyk2

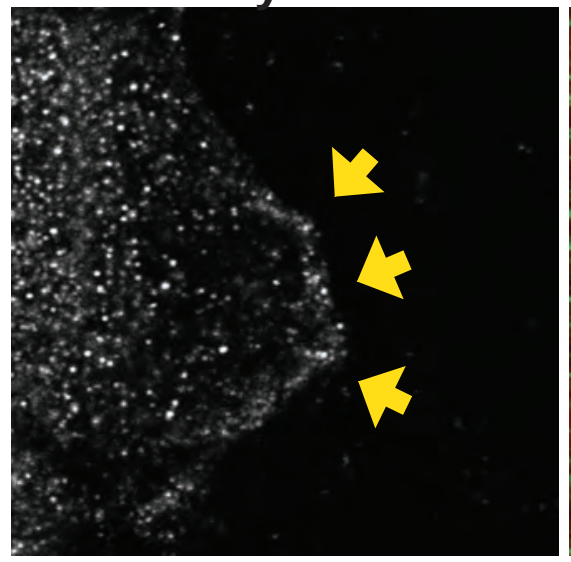

C

D

$\mathbf{F}$
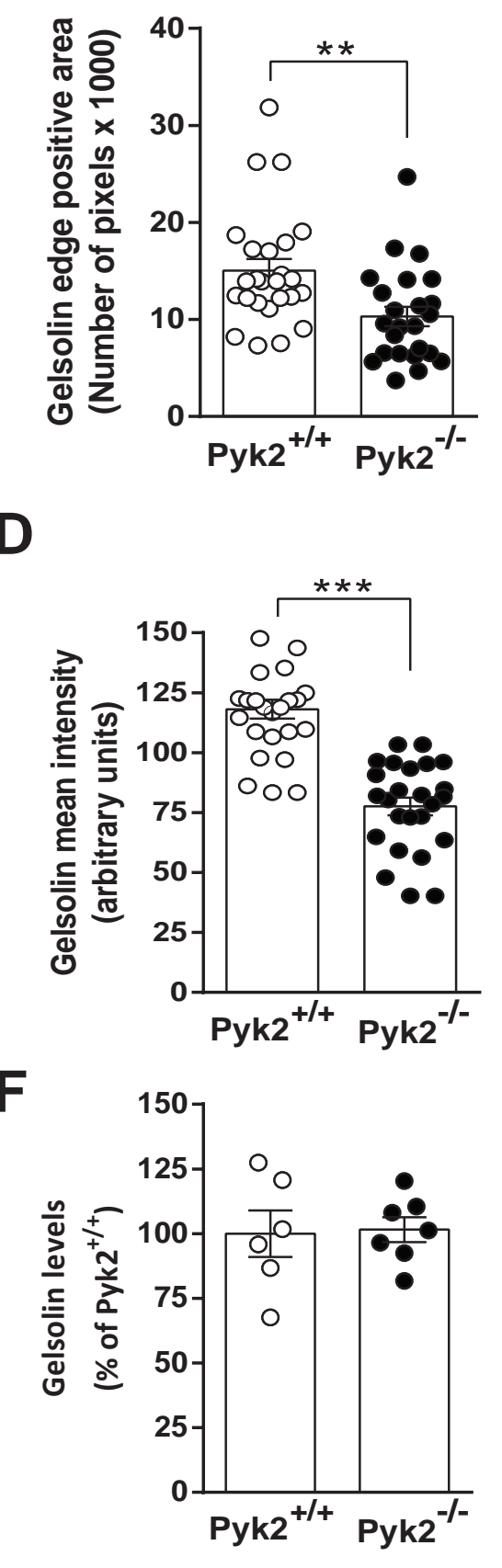

Phalloidin Pyk2

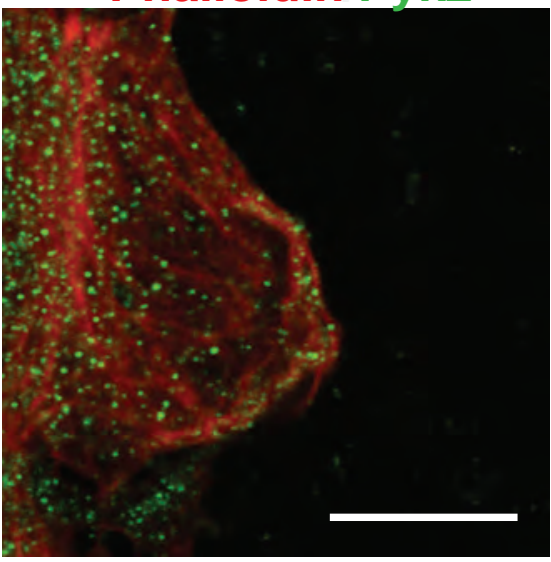

C

D 